\title{
The ZIC gene family encodes multi-functional proteins essential for patterning and morphogenesis
}

\author{
Rob Houtmeyers · Jacob Souopgui · Sabine Tejpar • \\ Ruth Arkell
}

Received: 7 September 2012 / Revised: 16 January 2013 / Accepted: 28 January 2013 / Published online: 27 February 2013

(C) Springer Basel 2013

\begin{abstract}
The zinc finger of the cerebellum gene (ZIC) discovered in Drosophila melanogaster (odd-paired) has five homologs in Xenopus, chicken, mice, and humans, and seven in zebrafish. This pattern of gene copy expansion is accompanied by a divergence in gene and protein structure, suggesting that Zic family members share some, but not all, functions. ZIC genes are implicated in neuroectodermal development and neural crest cell induction. All share conserved regions encoding zinc finger domains, however their heterogeneity and specification remain unexplained. In this review, the evolution, structure, and expression patterns of the ZIC homologs are described; specific functions attributable to individual family members are supported. A review of data from functional studies in Xenopus and murine models suggest that ZIC genes encode multifunctional proteins operating in a context-specific manner to drive critical events during embryogenesis. The identification of ZIC mutations in congenital syndromes highlights the relevance of these genes in human development.
\end{abstract}

R. Houtmeyers $(\bowtie) \cdot S$. Tejpar

Department of Oncology, Katholieke Universiteit Leuven, O\&N1, 3000 Leuven, Belgium

e-mail: rob.houtmeyers@med.kuleuven.be

S. Tejpar

e-mail: sabine.tejpar@med.kuleuven.be

R. Arkell

Research School of Biology, Australian National University, Canberra ACT 2601, Australia

J. Souopgui

Laboratoire de Génétique du Développement, Université Libre de Bruxelles, Rue des Professeurs Jeener et Brachet 12,

6041 Gosselies, Belgium
Keywords Zic genes $\cdot$ Mouse $\cdot$ Xenopus $\cdot$ Transcription . Neural development $\cdot$ Neurological disorders

\section{Structural features of the ZIC family proteins}

The Zic genes are orthologs of the Drosophila melanogaster pair rule gene odd-paired (opa). The first vertebrate member of this family was identified during a screen for cDNAs enriched in the murine cerebellum [1]. Since that time, the isolation and sequencing of ZIC genes from a wide variety of organisms [2-6] has enabled extensive comparative analysis of ZIC protein sequences, which has revealed a variety of structural elements (Fig. 1). The ZIC proteins are defined by the presence of a zinc finger domain that consists of five Cys2His2-type zinc fingers and which is most closely related to the zinc finger domain of the GLI, GLIS, and NKL families. The Zic zinc finger domain is distinguished by an atypical first zinc finger. Generally, one to five amino acid residues separate the two cysteines of a $\mathrm{C} 2 \mathrm{H} 2$ zinc finger. In Zic proteins, however, this number is both increased and highly variable, ranging from 6 to 38 in species so far examined $[6,7]$. Several functions have been ascribed to the zinc finger domain. Firstly, the zinc finger domain is able to bind DNA $[8,9]$. Secondly, the zinc finger domain participates in protein/protein interactions $[10,11]$. Thirdly, none of the ZIC proteins contain a canonical nuclear localization signal but the ZIC3 zinc finger domain (fingers 2-5) has been shown to be essential for this function and presumably harbors an interspersed nuclear localization signal $[12,13]$. As recently reviewed [14], interactions between ZIC and other proteins have also been shown to alter the sub-cellular location of the ZIC proteins and it is possible that the nucleocytoplasmic shuttling of the ZIC proteins is controlled by one or more interacting proteins. 

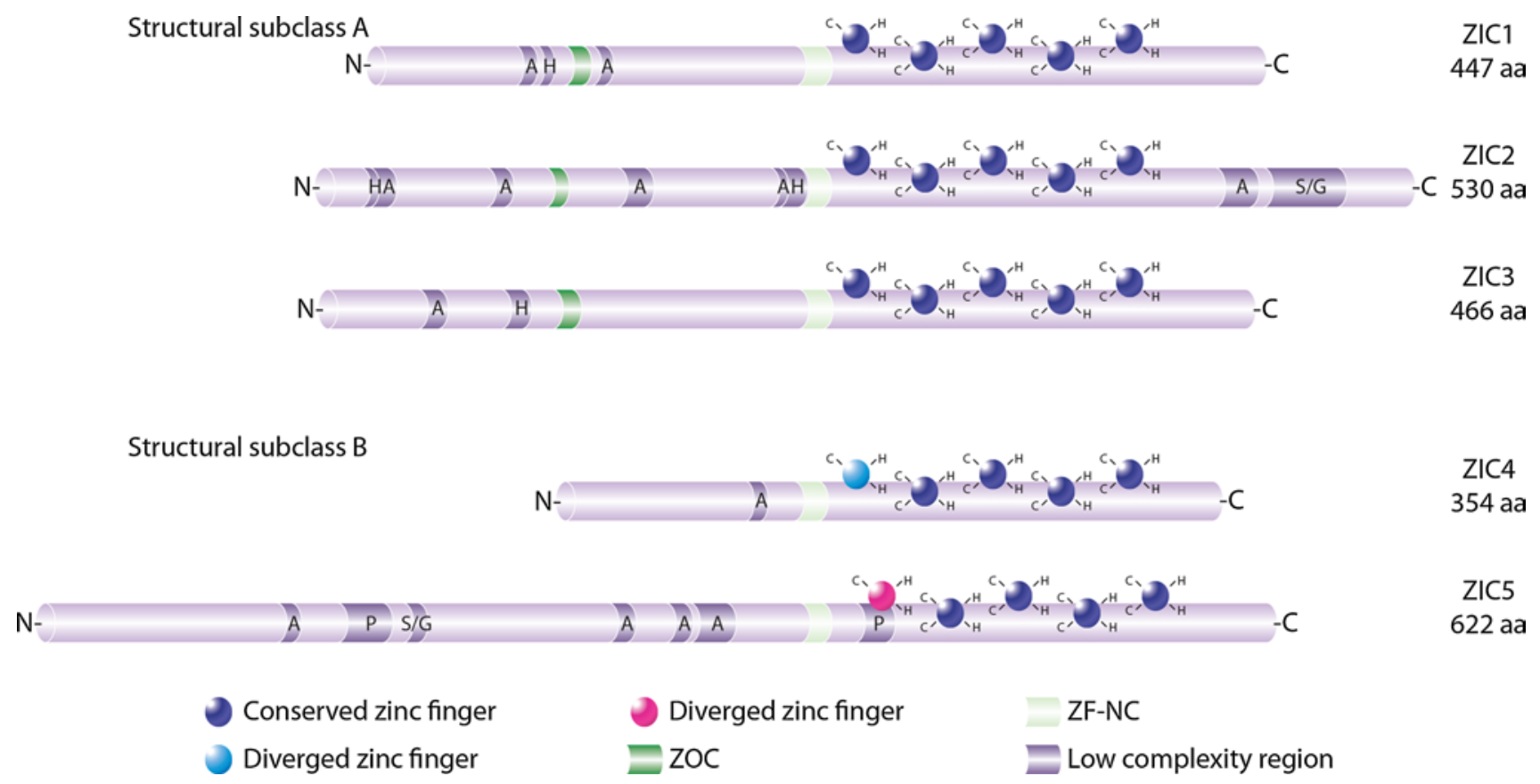

Fig. 1 Structural features of the Zic proteins. Each of the five human Zic proteins is depicted. All contain a zinc finger domain that consists of five tandem $\mathrm{C} 2 \mathrm{H} 2$-type zinc fingers. This domain is highly conserved with only the first zinc fingers of ZIC4 and ZIC5 showing some divergence. All five proteins also contain a short (14-21 amino acid) highly conserved domain immediately upstream of the zinc fingers, called the ZF-NC domain. Three of the proteins (ZIC1, ZIC2, and ZIC3) share another small domain (9-10 amino acid) of homology towards the $\mathrm{N}$ terminal of the protein called the ZOC motif. All

Domain mapping experiments have not conclusively identified the fingers responsible for the DNA and protein binding activities. A missense mutation that alters the second cysteine of the fourth zinc finger of murine Zic2 ablates DNA binding and causes a loss-of-function phenotype, indicating that this finger may be required for DNA binding. The mutant protein is able to interfere with the trans-activation ability of wildtype ZIC2 in cell-based assays, implying that the inactivation of the 4th zinc finger does not interfere with a critical protein/ protein interaction $[15,16]$. Additionally, structural analysis of the ZIC3 protein indicates that the first two zinc finger domains may not be canonical (DNA binding) C2H2-type zinc fingers. Instead, these fingers may together form a single structural unit called the tandem $\mathrm{CWCH} 2$ motif, the hallmark of which is a tryptophan residue located between the two canonical cysteines of each zinc finger [17]. This motif occurs in the first and second zinc finger of the Zic proteins in a wide range of metazoan species [6]. The strong conservation of the motif suggests biological significance as does the fact that a missense mutation of the tryptophan in the first zinc finger of ZIC3 is associated with congenital heart malformation. This mutation reduces protein stability and perturbs the nuclear localization of the protein [18]. The function of the proteins also contain low complexity regions with the major amino acid found at each low complexity region shown by the associated letter ( $A$ alanine, $H$ histidine, $P$ proline, $S / G$ serine/glycine). Expansion of the alanine repeat region located C-terminal of the ZIC2 zinc finger domain or at the N-terminus of the ZIC3 protein is associated with human pathology. On the basis of the presence or absence of the ZOC motif and the degree of conservation within the first zinc finger domain the Zic proteins can be divided into two distinct structural subclasses

$\mathrm{CWCH} 2$ motif is not known but it may be imagined that it could modulate the DNA binding capacity of the remaining canonical zinc fingers (for example, it may influence the position of the transcription factor with respect to the DNA), it could serve as a cap or insulator structure to isolate the DNA binding fingers from the $\mathrm{N}$-terminal portion of the protein, or it could participate in protein-protein interactions.

Two further domains have been identified on the basis of sequence homology. A small, highly conserved domain (1421 aa in size) is located immediately N-terminal of the zinc finger domain in each of the vertebrate ZIC proteins. This region has been termed the zinc finger $\mathrm{N}$-terminally conserved domain (ZF-NC) but its function is not known [6]. Additionally, a small (9-10 aa in size) N-terminally located domain is conserved amongst a subset of the vertebrate ZIC proteins. The Drosophila odd paired gene also contains this domain and it was therefore named the ZIC/Odd paired conserved motif (ZOC motif) $[2,7]$. This domain has been found to be required for protein-protein interactions, for example, each of the mammalian ZIC proteins that contain this domain (ZIC1, ZIC2, and ZIC3) have been shown to bind MDFI (I-mfa), an inhibitor of the basic helix-loop-helix type of transcription factors via the ZOC motif [19]. Other structural features of 
the ZIC family include low-complexity regions located outside the zinc finger domain (poly-alanine, -histidine, -proline, and -serine/glycine tracts). Interestingly, expansion mutations of the C-terminal alanine tract of ZIC2 and the N-terminal alanine tract of ZIC3 are associated with human pathology. Alanine expansion mutations of ZIC2 are associated with holoprosencephaly (HPE) patients [20] and one ZIC3 expansion mutation is found in a Heterotaxy proband [21]. Experiments in vitro reveal that the ZIC2 mutations lead to a marked decrease in DNA binding activity of ZIC2 protein while the zinc finger domain remains intact [16].

As shown in Fig. 1, we propose that based on the presence or absence of the ZOC motif and on the spacing between the cysteine residues of the first zinc finger domain, the ZIC proteins can be subdivided into two distinct subclasses. Structural subclass A consists of ZIC1, ZIC2, and ZIC3 and is characterized by the presence of the ZOC box and conserved nature of zinc finger 1 . Structural subclass B consists of ZIC4 and ZIC5, both of which lack the ZOC box and have a diverged first zinc finger.

\section{Molecular function of the ZIC proteins}

The ZIC proteins are thought to regulate the transcriptional activity of target genes. As recently reviewed [14], there is now good evidence that the ZIC proteins can influence gene expression, not only as classical transcription factors through direct DNA binding via their zinc finger domains but also as co-factors by binding to other transcription factors. Recently, we and others established that the ZIC proteins can repress canonical WNT signaling target genes by binding directly to the members of the TCF (transcription factor) protein family through its zinc finger domain. This ZIC-mediated inhibition of WNT signaling occurs without the ZIC proteins contacting DNA [10, 22]. These recent studies augment previous observations that suggest that the ZIC proteins can influence the transcriptional outcome of Hedgehog signaling without contacting DNA by binding to the GLI proteins [23].

Genomic arrangement and evolution of the vertebrate ZIC genes

The sequencing, assembly, and annotation of multiple genomes over the past decade has revealed that the Zic genes have a relatively unusual arrangement within the genomes of all vertebrates examined. Figure 2 shows the arrangement of the Zic genes (as shown in the Ensembl database) in the teleost lineage (as represented by zebrafish) as well as in amphibia (represented by Xenopus) and in mammals (represented by human and mouse). It can be seen that in each case at least some of the genes exist as tandem copies, divergently transcribed from an intervening bidirectional promoter. There are few examples of these types of paralog gene clusters being retained over large evolutionary distances but notably three other well-characterized examples (the Hox, Dlx, and Fox genes) all encode transcription factors critical for embryonic patterning and morphogenesis. In the case of the Zic genes, each of the retained pairs consists of one member from each structural subclass. Based on phylogenetic analysis of Zic gene sequences and intron/exon position, Aruga et al. [6] have proposed a hypothetical model of Zic gene evolution, shown in Fig. 3. In this model, the ancestral single-copy Zic gene contained one intron and a full set of conserved structural domains. Following tandem duplication of this gene, some variation occurred such that one gene copy acquired an additional intron and the other gene copy underwent sequence divergence with the breakdown of the ZOC motif and increased divergence of zinc finger 1. Subsequently, the genome duplication events proposed to have taken place early in the vertebrate lineage, presumably led to the generation of eight Zic genes arranged in four bigene clusters with each cluster containing a Zic gene from structural subclass A and B. Gene loss would largely account for the Zic gene copy number now seen in each particular vertebrate. As can be seen in Fig. 2, the zebrafish has seven Zic genes while other characterized vertebrates have five. This discrepancy is accounted for by two factors (1) the retention in the teleost lineage of the Zic3 bigene pair (designated zico) and (2) independent duplication of the Zic2 gene leading to two copies of this gene, one paired with Zic5 as in other vertebrates (and designated zic $2 a$ in zebrafish) and the other an unlinked copy (designated zic2b) [24]. The zebrafish zic6 is distinguished by the lack of the ZF-NC domain [24], the only of the vertebrate genes depicted in Fig. 2 to lack this domain. In addition to the differences in the teleost lineage, Fig. 2 demonstrates that in both mammalian genomes examined here the ZIC4 gene has become less compact with the addition of introns between the coding and non-coding exons and a novel intron that divides the sequence corresponding to the first coding exon in each of the other depicted genes. Examination of other mammalian genomes suggests that this pattern is not unique to mice and man but may be more widespread in the mammalian lineage.

The different features of the Zic gene arrangement in the zebrafish genome provide additional opportunities for functional divergence and there is some evidence that the function of individual Zic genes is different in zebrafish and mammals. This is exemplified by the finding that in zebrafish zicl loss-of-function leads to the distinctive phenotype of cyclopia (the formation of a single, ventrally displaced eye) [25], whereas in mouse and man this phenotype is associated with loss of ZIC2 function [16, 26]. It has long been recognized that gene family expansion accompanied by the unusual arrangement of the Zic genes generates particular difficulties when studying their function. The genes are likely to exhibit broad overlap in gene expression and 
Fig. 2 The genomic arrangement of vertebrate $\mathrm{Zic}$ genes. The genomic arrangement of the Zic genes (as shown on the Ensembl genome browser: Human Assembly GRCh37. p8, Feb 2009, Mouse Assembly GRCm38, Jan 2012, Xenopus tropicalis Assembly JGI 4.2, Nov 2009. Zebrafish Assembly $\mathrm{Zv9}$, Apr 2010) is depicted. The structural subclass A Zic genes are shown on the left and the structural subclass 2 genes are shown on the right. The human, mouse and Xenopus genomes contain five Zic genes arranged as two tandem pairs (ZICl/4 and $Z I C 2 / 5$ ) with an unpaired ZIC3 gene. The Zebrafish genome has seven Zic genes, three tandem pairs (zicl/4, $z i c 2 a / z i c 5$, and $z i c 3 / 6$ ) and an additional gene $z i c 2 b$ most likely derived by independent duplication of $z i c 2 a$

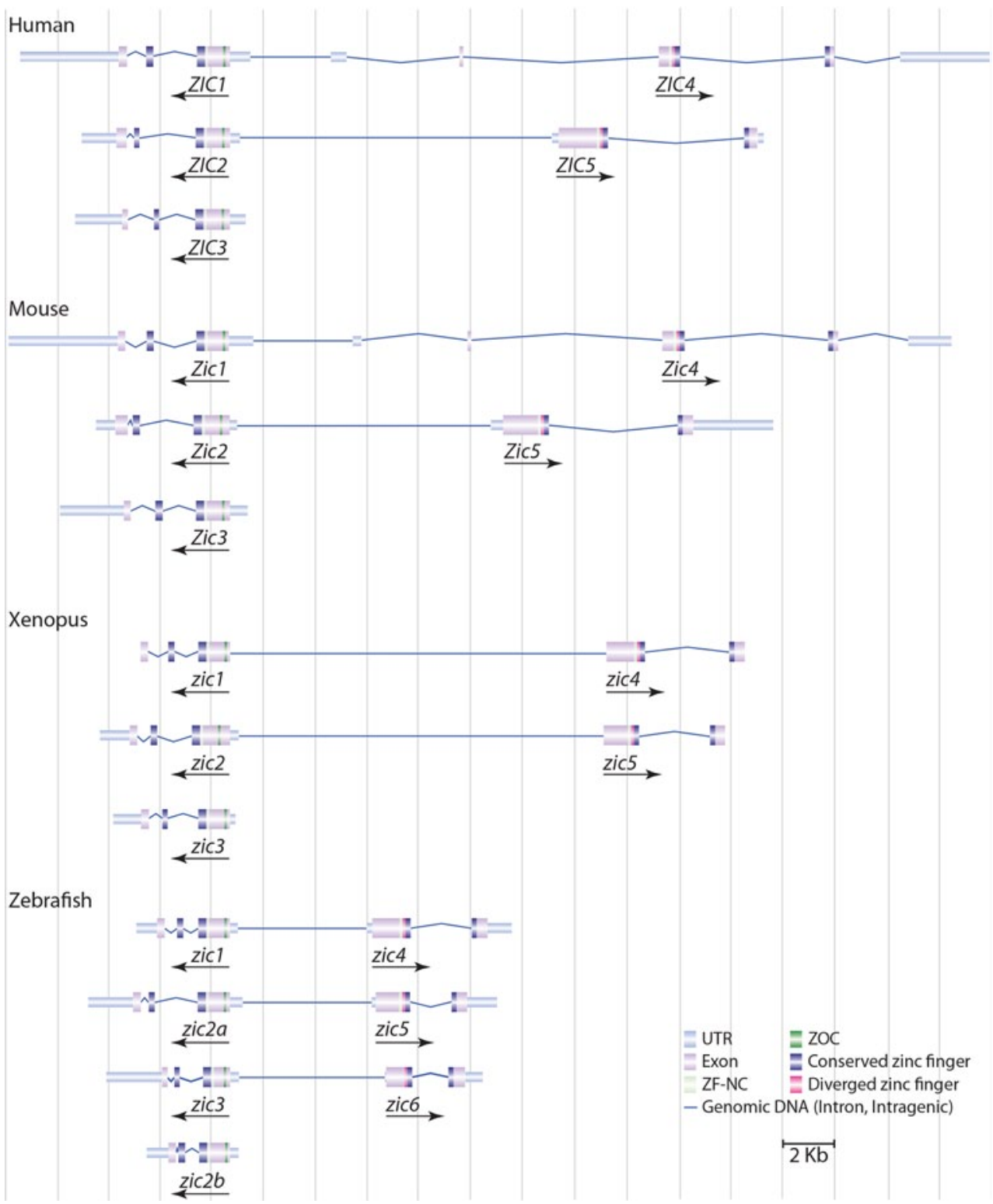

are likely to recognize the same DNA-binding motifs; they may also share protein partners and could participate in cross regulation of family members at both the gene expression and protein interaction levels.

Human and model organism genetic studies have repeatedly demonstrated that the Zic genes are required for embryonic development (as reviewed in [27-29]) and in some cases we have now been able to identify the embryonic stage and tissue in which Zic gene function is required in order to prevent the respective associated congenital defect. More study is required, however, to determine the precise molecular mechanisms of Zic gene function and regulation. Additionally, it is likely that both germ-line and somatic mutation of the Zic genes constitute as-yet-unrecognized risk factors for other diseases and disorders. As a basis for furthering our understanding of how the Zic genes contribute to human embryonic development and adult homeostasis we now review data from gene expression studies and from experiments that remove or increase Zic gene expression. We focus on experiments conducted in the two model organisms (mouse and Xenopus laevis) for which current genome annotations indicate a largely conserved gene arrangement with the human genome and for which considerable knowledge has now been amassed regarding Zic gene expression and the consequence of altered $\mathrm{Zic}$ gene dosage.

Spatial-temporal expression of the vertebrate ZIC genes

\section{Murine Zic gene expression}

The tandem gene arrangement of the vertebrate ZIC genes suggests the paired members may share regulatory regions 


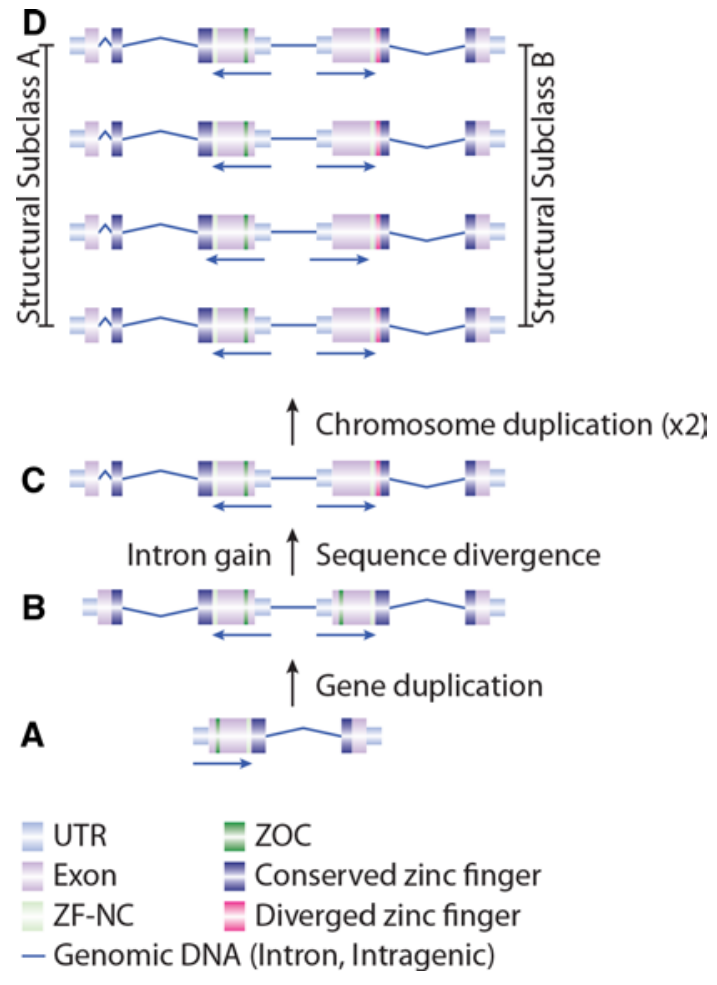

Fig. 3 The vertebrate Zic gene family expansion. A hypothetical model of Zic gene expansion early in the vertebrate lineage is depicted (adapted from ARUGA, 2006). The ancestral zic gene, which contained a single intron and each of the conserved protein domains (ZOC motif, ZF-NC, and zinc finger domain), first underwent tandem duplication to generate two divergently transcribed genes. Prior to chromosome duplication, the founding member of the structural subclass A genes gained an intron and the founding B class member lost the ZOC motif and changed the amino acid sequence of the first zinc finger. Two genome duplications resulted in eight $\mathrm{Zic}$ genes with subsequent gene loss, duplication, and intron gain giving rise to the genomic arrangements depicted in Fig. 2

and may be co-expressed. The finding that individual murine Zic genes when mutated give distinct phenotypes suggests however that Zic expression patterns may have at least partially diverged during evolution. Analysis of murine Zic mRNA expression patterns shows that the family members can be divided into two broad groups and supports the notion that some regulatory regions have been conserved while others have diverged. The expression of Zic2, Zic3, and Zic5 initiates prior to, and is maintained throughout, gastrulation. During the later events of patterning, morphogenesis and early organogenesis Zic2, Zic3, and Zic5 expression continues in a tissue-specific manner and the expression of Zic1 and Zic4 is initiated. All five Zic genes are therefore co-expressed in some cells during embryonic development, providing the opportunity for heterotypic protein interactions and/or functional redundancy amongst the family members.
Zic2 appears to be the earliest of the murine Zic genes to be expressed, and expression occurs within the inner cell mass of the blastocyst at 3.5 days post-coitum (dpc) [30]. The expression of Zic3 and Zic5 has also been detected in embryonic stem cells (ES) cells in which ZIC3 proteins have been immunoprecipitated [9], and Zic5 transcripts detected [31]. By analogy, it seems likely that Zic2 and Zic3 are expressed in the inner cell mass at the blastocyst stage. Consistent with this possibility Zic2, Zic3, and Zic5 transcripts have been detected in the embryonic and extraembryonic ectoderm (or epiblast) of the immediate post-implantation stage embryo (the tissue derived from the inner cell mass of the blastocyst) [32, 33]. The expression of Zic2, Zic3, and Zic5 is maintained in the ectoderm during gastrulation and transcripts are also found in some of the newly formed mesoderm that ingresses through the primitive streak [32, 33]. Notably, none of the Zic genes are expressed in the mesoderm that moves into the extraembryonic region. Despite the broad similarities in expression of these three genes during gastrulation, there are some differences. For example, Zic3 is uniquely expressed in the anterior of the early gastrula in a region that corresponds to the prechordal plate and anterior definitive endoderm. At mid-gastrulation, Zic2 is transiently and uniquely expressed in the node (Fig. 4), whereas at early somite stages Zic3 is the only Zic family member expressed at the node [32]. By the early headfold stage of development the expression of all three Zic genes in extraembryonic ectoderm has ceased and expression in the embryonic ectoderm is restricted to neuroectoderm. As neurulation progresses, Zic expression in neuroectoderm becomes limited to the most dorsal region; the future site of neural crest cell and dorsal neuron production. Additionally, Zic expression is maintained in both the pre-somitic (Zic2, Zic3, and Zic5) and somitic (Zic1 5) populations of the lateral mesoderm.

Zicl was initially reported to be expressed in a similar but more restricted pattern compared with Zic2 and Zic3 during murine gastrulation [34]. These in situ hybridization studies were not reproduced by Elms et al. [32], and an absence of Zic1 mRNA was confirmed by RT-PCR analysis of gastrulation stage embryos. It appears that during murine development both Zicl and Zic4 are first expressed at the somite stage of development in the neuroectoderm and somitic mesoderm. By $9.5 \mathrm{dpc}$, transcripts from all five murine Zic genes are found in the dorsal spinal cord, the dorsal cranial neural tube, and in the somites. Subtle differences in the expression domains of the Zic genes persist, for example Zic4 is never expressed within the roof plate of the neural tube and has a more restricted expression domain in the dorsal sclerotome of the somites [32-35]. One day later, the expression of Zic2, Zic3, and Zic5 is initiated in newly developing eye and in the limb buds. Several Zic family members are expressed at later stages of eye development in 
the population of progenitor cells of the developing retina. Nine different types of cells originate from these progenitor cells and microarray analysis found that Zicl, Zic2, and Zic3 are expressed in SSEA-1-positive cells at $14 \mathrm{dpc}$. This expression of Zicl and Zic2 decreased and disappears over time, while in contrast, Zic3 expression remains until adulthood [34, 36-39].

At later stages of development, neural Zic expression patterns become spatially limited. The progenitor cells of the thalamus, preoptic area, the septum, cortical hem, and the retina all share a specific pattern of Zic gene expression and have been investigated in Zic gene functional analyses over the past few years. The populations of progenitor cells in the brain, such as the granular layer of the cerebellum express all Zic family members, even in adult stages $[34,36]$. The expression signal becomes generally more restricted at embryonic day 12.5 when it becomes limited to the dorsal neural tube and the dorsal midline in the brain. Remarkably, expression of Zic4 at these stages can be mainly found in the septum.

From 12 dpc onwards, Zicl-3 are all expressed in medial neural tissues including the cortical hem, the septum and the ventricular and sub-ventricular zone. In the marginal zones around the brain, the expression of Zic3 is less compared with the other two members; all are expressed in the nucleus of the meningeal fibroblasts. These regions of the brain are thought to be the source of Cajal-Retzius cells and continue to express the Zic family members until adulthood $[34,36]$.

\section{Xenopus zic gene expression}

The Xenopus zic gene family is characterized by genespecific but also partially overlapping expression patterns over time and is mostly limited to progenitor tissue of the future central nervous system (CNS). Prior to fertilization, $z i c 2$ transcripts have been be detected in the oocyte. Zygotic expression of all zic family members (except zic4) can be found at the onset of gastrulation and in prospective neural tissues. Very weak zic4 expression was detected at the prospective neural fold region of the stage 11.5 mid-gastrula [40]. Expression of all zic family members continued at the neural plate border during early neurulation, neural crest formation, and at the dorsal central nervous system at later neurula stages. The spatio-temporal and partially overlapping expression patterns of this family make this model organism complex but simultaneously attractive to study.

In a functional screen using a maternal cDNA library from Xenopus laevis, Houston and Wylie [41] discovered high expression levels of maternal zic2. This supported the previous findings of Nakata et al. [42] who had screened for the primary expression patterns of all zic family members. They also detected zic 5 transcripts in the same cDNA extract, although this was not confirmed by Houston and Wylie.

All zic family members (except for zic4) are expressed at mid-blastula stages. During gastrulation, zic expression becomes limited to the prospective neural plate. Unlike for murine Zic expression patterns at this stage, most of the Xenopus zic genes are expressed in overlapping patterns, so only subtle spatial-temporal differences in expression can be observed. In general, zic 1 and $z i c 3$ expression is more widespread compared with zic2 and zic5. The uncoupled $z i c 3$ is uniquely expressed in the more caudal lateral plate mesoderm. Zic2 and zic3 are the only members that are expressed along the complete AP axis while zicl and zic4 expression is found in the future hyoid and branchial arches. The selective expression of zic5 is found mostly at the anterior neuroectodermal ridge [40, 42-44].

Nevertheless, all zic genes are reportedly expressed at the neural fold where they play an essential role during neural patterning [42-44]. To date, Xenopus laevis is the only vertebrate model where the expression of all zic family members at the neural plate border and at the dorsal side of the neural tube after closure is linked to neural crest cell production. Alterations in zic expression result in clear phenotypic differences in terms of the production and migration of neural crest cells. At later neurula stages, expression of all zic members continues in the dorsal CNS while their expression patterns elsewhere become further restricted. In the somites, expression patterns are mostly restricted to zicl and zic4 transcripts although zic2 is expressed to a lesser extent and is more ventrally located. During the early tailbud stages zicl-3 are all dorsally expressed in the forebrain, midbrain, and hindbrain and are found at later stages in the telencephalon and di-/mesensephalon border, in a largely overlapping pattern. Zic5 transcripts are only detected in the midbrain and hindbrain. Clear differences are observed at the eye vesicle where zic2 and zic5 expression are mostly observed, further highlighting the coupled expression of these two head-to-head placed genes. The expression of zic2 and zic5 is limited here to the ciliary marginal zone of the retina. In contrast, zic2 expression is observed during somitogenesis and accompanied by zicl and zic4 but not by zic5 expression. As organogenesis progresses, these expression patterns are more restricted and remain present until later stages $[3,40]$.

\section{Functional analysis of the Zic genes}

Murine Zic genes

Mutational analysis of the murine Zic genes has played an important role revealing the function of these proteins in mammalian biology and there is now an extensive catalogue 
Table 1 Murine Zic loss-of-function phenotypes

\begin{tabular}{|c|c|c|}
\hline Zic phenotypes & Zic genotypes & Authors (reference) \\
\hline Primitive streak dysgenesis & $Z i c 3^{-1-}, Z i c 3^{-/ Y}$ & Ware et al. [48] \\
\hline $\begin{array}{l}\text { Failure of anterior notochord } \\
\text { production }\end{array}$ & $Z i c 2^{K u / K u}$ & Warr et al. [26] \\
\hline Left-right axis defect & $Z i c 3^{\mathrm{Bn} /+}, \mathrm{Zic} 3^{B n / B n}, \mathrm{Zic} 3^{B n / Y}, \mathrm{Zic}^{-/-}, \mathrm{Zic}^{-/ Y}$ & Carrel et al. [55], Purandare et al. [45] \\
\hline \multicolumn{3}{|l|}{ Patterning and morphogenesis } \\
\hline Neural tube defect: exencephaly & 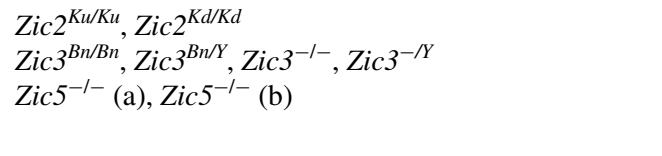 & $\begin{array}{l}\text { Elms et al. [15], Nagai et al. [61], } \\
\text { Klootwijk et al. [44], Purandare et al. } \\
\text { [45], Inoue et al. [31], Furushima et al. } \\
\text { [57] }\end{array}$ \\
\hline $\begin{array}{l}\text { Neural tube defect: spina bifida } \\
\text { (and curled tail) }\end{array}$ & $\begin{array}{l}Z i c 2^{K u /+}, Z i c 2^{K d / K d} \\
Z i c 3^{B n / B n}, Z i c 3^{B n / Y}\end{array}$ & $\begin{array}{l}\text { Elms et al. [15], Nagai et al. [61], Garber } \\
\text { et al. [74], Johnson et al. [96], Klootwijk } \\
\text { et al. [56] }\end{array}$ \\
\hline Classical holoprosencephaly & $Z i c 2^{K u / K u}$ & Warr et al. [26] \\
\hline $\begin{array}{l}\text { Roof plate abnormality/middle } \\
\text { interhemispheric variant } \\
\text { Holoprosencephaly }\end{array}$ & $\begin{array}{l}Z i c 2^{K d / K d} \\
Z i c 5^{-/-}(\mathrm{b})\end{array}$ & Nagai et al. [61], Furushima et al. [57] \\
\hline Hindbrain patterning & $Z i c 2^{K u / K u}$ & Elms et al. [15] \\
\hline Dorsal spinal cord hypoplasia & $Z_{i c 1}{ }^{-1-}$ & Aruga et al. [98] \\
\hline $\begin{array}{l}\text { Cranial neural crest deficit/ } \\
\text { craniofacial skeletal defect }\end{array}$ & $\begin{array}{l}Z i c 2^{K u / K u} \\
Z i c 5^{-/-} \text {(a), } Z i c 5^{-/-} \text {(b) }\end{array}$ & $\begin{array}{l}\text { Elms et al. [15], Inoue et al. [31], } \\
\text { Furushima et al. [57] }\end{array}$ \\
\hline Trunk neural crest deficit & $Z i c 2^{K u / K u}$ & Elms et al. [15] \\
\hline Omphalocele & $Z i c 3^{B n / B n}, Z i c 3^{B n / Y}$ & Klootwijk et al. [44] \\
\hline Cleft lip & $Z i c 3^{B n / B n}, Z i c 3^{B n / Y}$ & Klootwijk et al. [44] \\
\hline $\begin{array}{l}\text { Skeletal defect: tail (reduced } \\
\text { number of and/or dysmorphic } \\
\text { caudal vertebrae) }\end{array}$ & $\begin{array}{l}Z i c 2^{K d / K d} \\
Z i c 3^{\mathrm{Bn} /+}, \mathrm{Zic3}^{B n / B n}, \mathrm{Zic}^{\mathrm{Bn} / Y}, \mathrm{Zic3}^{+/-}, \mathrm{Zic3}^{-/-}, \mathrm{Zic3}^{-/ Y} \\
\mathrm{Zic5}^{-/-} \text {(a) }\end{array}$ & $\begin{array}{l}\text { Nagai et al. [61] Gruneberg [63], } \\
\text { Purandare et al. [45], Inoue et al. [31] }\end{array}$ \\
\hline \multicolumn{3}{|l|}{ Organogenesis } \\
\hline $\begin{array}{l}\text { Forebrain: dysgenesis of } \\
\text { medial structures }\end{array}$ & 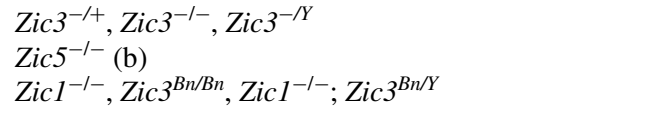 & $\begin{array}{l}\text { Purandare et al. [45], Furushima et al. [57] } \\
\text { Inoue et al. [64] }\end{array}$ \\
\hline Forebrain: enlarged ventricles & ${Z Z i c 5^{-1-}}_{(b)}$ & Furushima et al. [57] \\
\hline Cerebellum: reduced size & 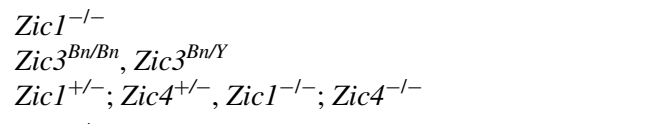 & $\begin{array}{l}\text { Aruga et al. }[29,65] \\
\text { Blank et al. [66], Grinberg et al. [67] }\end{array}$ \\
\hline Cerebellum: folia patterning & $\begin{array}{l}Z i c 1^{-/-} \\
Z_{i c 3^{B n / B n}}, \mathrm{Zic}^{\mathrm{Bn} / Y} \\
\mathrm{Zic1}^{+/-} ; \mathrm{Zic4}^{+/-}, \mathrm{Zic1}^{-/-} ; \mathrm{Zic4}^{-/-}, \mathrm{Zic1}^{+-} ; \mathrm{Zic2}^{\mathrm{Kd} /+}\end{array}$ & $\begin{array}{l}\text { Aruga et al. [29, 65], Grinberg et al. [67], } \\
\text { Blank et al. [66], Aruga et al. [98] }\end{array}$ \\
\hline Microcephaly & $\begin{array}{l}Z i c 2^{K d / K d} \\
Z i c 5^{-/-}(\mathrm{b})\end{array}$ & Furushima et al. [57], Nagai et al. [61] \\
\hline Skeletal defect: sternum/ribs & $\begin{array}{l}Z i c 1^{-l-} \\
Z_{i c 5^{-I-}} \text { (a) }\end{array}$ & Inoue et al. [31], Aruga et al. [72] \\
\hline Skeletal defect: vertebral arches & $\begin{array}{l}Z i c 1^{-/-} \\
Z i c 2^{K d / K d} \\
Z i c 3^{\mathrm{Bn} /+}, \mathrm{Zic3}^{B n / B n}, \mathrm{Zic3}^{\mathrm{Bn} / Y}, \mathrm{Zic3}^{+/-}, \mathrm{Zic3}^{-/-}, \mathrm{Zic3}^{-/ Y} \\
\mathrm{Zic5}^{-/-} \text {(a) } \\
\mathrm{Zic2}^{\mathrm{Kd/+}} ; \mathrm{Zic3^{Bn/Y }}\end{array}$ & $\begin{array}{l}\text { Aruga et al. [72], } \\
\text { Nagai et al. [61], } \\
\text { Gruneberg et al. [63], Purandare et al. [45], } \\
\text { Inoue et al. [31], } \\
\text { Inoue et al. [64] }\end{array}$ \\
\hline Skeletal defect: vertebral bodies & $Z i c 2^{K d /+} ; Z i c 3^{B n / Y}$ & Inoue et al. [64] \\
\hline Skeletal defect: limb & $\begin{array}{l}Z i c 2^{K d / K d} \\
Z i c 3^{B n / B n}, Z i c 3^{B n / Y}\end{array}$ & $\begin{array}{l}\text { Nagai et al. [61], } \\
\text { Garber [74] }\end{array}$ \\
\hline Eye: microphthalmia/anophthalmia & $\begin{array}{l}\mathrm{Zic} 2^{K d / K d} \\
\mathrm{Zic} 3^{B n / B n}, \mathrm{Zic} 3^{B n / Y} \\
Z_{i c 5^{-/-}}(\mathrm{b})\end{array}$ & $\begin{array}{l}\text { Herrara et al. [69], } \\
\text { Klootwijk et al. [44], } \\
\text { Furushima et al. [57] }\end{array}$ \\
\hline Eye: optic chiasm dysmorphology & $Z i c 2^{K d / K d}$ & Herrara et al. [69] \\
\hline
\end{tabular}


Table 1 continued

\begin{tabular}{|c|c|c|}
\hline Zic phenotypes & Zic genotypes & Authors (reference) \\
\hline $\begin{array}{l}\text { Eye: aberrant ipsilateral projection } \\
\text { of retinal ganglion cells }\end{array}$ & $Z i c 2^{K d /+}, Z i c 2^{K d / K d}$ & Herrara et al. [69] \\
\hline \multicolumn{3}{|l|}{ Post birth } \\
\hline Viability: embryonic lethality & $\begin{array}{l}Z i c 2^{K u / K u} \\
Z i c 3^{B n / B n}, Z i c 3^{B n / Y}, Z i c 3^{-/-}, Z i c 3^{-/ Y}\end{array}$ & $\begin{array}{l}\text { Elms et al. [15], } \\
\text { Garber et al. [74], Purandare et al. [45] }\end{array}$ \\
\hline Viability: peri-natal lethality & $\begin{array}{l}Z i c 2^{K d / K d} \\
Z i c 5^{-1-}(\mathrm{b})\end{array}$ & Inoue et al. [31], Nagai et al. [61] \\
\hline Viability: juvenile lethality & 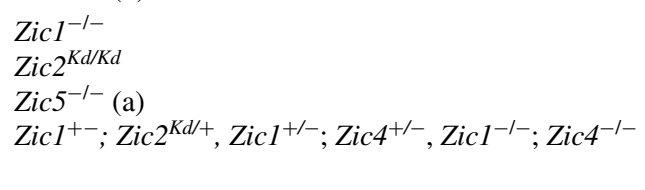 & $\begin{array}{l}\text { Aruga et al. [65], } \\
\text { Nagai et al. [61], } \\
\text { Inuoe et al. [31], } \\
\text { Aruga et al. [98], Grinberg et al. [67], } \\
\text { Blank et al. [66] }\end{array}$ \\
\hline Small at birth & $\begin{array}{l}\mathrm{Zic} 2^{K d / K d} \\
\mathrm{Zic}_{3} 3^{B n / B n}, \mathrm{Zic}^{\mathrm{Bn} / Y} \\
\mathrm{Zic5}^{-/-} \text {(a) } \\
\mathrm{Zic1}^{+-} ; \mathrm{Zic4}^{+/-}, \mathrm{Zic1}^{-/-} ; \mathrm{Zic4}^{-/-}\end{array}$ & $\begin{array}{l}\text { Nagai et al. [61], } \\
\text { Garber et al. [74] } \\
\text { Inoue et al. [31], } \\
\text { Grinberg et al. [67], Blank et al. [66] }\end{array}$ \\
\hline Behavioral: pre-pulse inhibition & $\mathrm{Zic} 2^{K d /+}$ & Ogura et al. [68] \\
\hline Behavioral: motor control & $\begin{array}{l}\mathrm{Zic1}^{+/-}, \mathrm{Zic1}^{-/-} \\
\mathrm{Zic3}^{\mathrm{Bn} / \mathrm{Bn}}, \mathrm{Zic3}^{\mathrm{Bn} / \mathrm{Y}} \\
\mathrm{Zic1}^{+/-} ; \mathrm{Zic4}^{+/-}, \mathrm{Zic1}^{-/-}, \mathrm{Zic4}^{-/-}\end{array}$ & $\begin{array}{l}\text { Ogura et al. [68], } \\
\text { Aruga et al. [29], } \\
\text { Grinberg et al. [67], } \\
\text { Blank et al. [66] }\end{array}$ \\
\hline Behavioral: abnormal gait and posture & $\begin{array}{l}Z i c 5^{-/-} \text {(a) } \\
Z_{i c 1^{+-}} ; \mathrm{Zic2} 2^{K d /+}\end{array}$ & $\begin{array}{l}\text { Inoue et al. [31], } \\
\text { Aruga et al. [98] }\end{array}$ \\
\hline Hydrocephalus & $\begin{array}{l}Z i c 5^{-1-} \text { (a) } \\
Z i c 1^{+-} ; Z i c 2^{K d /+}\end{array}$ & $\begin{array}{l}\text { Inoue et al. [31], } \\
\text { Aruga et al. [98] }\end{array}$ \\
\hline
\end{tabular}

(a) Zic5 $5^{\text {TmlJaru }}$ strain; (b) Zic5 $5^{\text {TmlSia }}$ strain

of processes, tissues, and organs known to be affected by loss of normal activity of one or more Zic proteins. The majority of available mouse alleles carry severe loss-offunction mutations and are primarily useful for studying the earliest function of each of the Zic proteins. The analysis of these alleles shows that $\mathrm{Zic}$ gene expression is required for the development of the embryonic axes, for many processes during the development of the CNS and for the development of the visual and musculo-skeletal systems. Importantly, where tested, the murine gene mutations give rise to phenotypes associated with mutation of the orthologous human ZIC gene, suggesting that the mouse mutants serve as good models for investigating the etiology of $Z I C$-associated human disorders (summarized in Table 1).

\section{Zic function at gastrulation}

The first developmental process known to require Zic function is gastrulation. In mouse embryos, the onset of gastrulation is marked by the formation of the primitive streak at the future posterior of the embryo. Cells delaminate from the embryonic ectoderm, ingress through the primitive streak, and differentiate into mesoderm and endoderm. The ectoderm at the future anterior of the embryo does not ingress through the primitive streak but differentiates in situ into the neural and non-neural ectoderm of the conceptus. Embryos that lack Zic3, either due to a spontaneous (bent tail, Bn) or targeted (Zic3 $3^{T m 1 B c a}$ ) deletion of the locus, exhibit a range of phenotypes [44, 45]. Some embryos have defects that are obvious by the onset of gastrulation and which imply a role for Zic3 in the formation of the primitive streak and in the differentiation of the mesoderm and endoderm [46]. This is consistent with the broad expression of Zic3 in the ectoderm of the early gastrula and in the primitive streak [32, 47]. Other Zic3 null embryos do not exhibit a defect until late in gastrulation at a stage when the left-right (L-R) embryonic axis is being established. The L-R axis is crucial to normal development of vertebrate embryos since despite their external symmetric appearance, all species contain characteristic internal asymmetries. The term heterotaxy is used to describe a particular disturbance of $\mathrm{L}-\mathrm{R}$ axis formation and mutations in both murine Zic3 and human ZIC3 are associated with the condition $[13,45,47]$. Heterotaxy results in congenital abnormalities of a wide range of midline structures and frequently includes heart defects. At mid-gestation, approximately $50 \%$ of Zic3 null embryos have overt heart abnormalities that are consistent with incorrect establishment of the L-R axis [48]. The correct establishment of 
the $\mathrm{L}-\mathrm{R}$ axis requires NODAL signaling during the early somite-stages at a specialized part of the primitive streak called the node. Zic3 is expressed at the node of the early somite embryo [32] and the penetrance of $\mathrm{Zic}^{-1-}$ heart phenotypes is increased in embryos that are also haploinsufficient for Nodal [48]. It is likely that ZIC3 plays a direct role in the establishment of the L-R axis, but it is difficult to exclude the possibility that the observed L-R axis defects are secondary to earlier abnormalities in the establishment of the primitive streak and node.

Zic2 function is also required during gastrulation to ensure that the cells of the anterior notochord are produced. These cells should emerge from the node of the mid-gastrula, but an insufficient number of anterior notochord cells are found in embryos homozygous for a missense mutation (kumba: $K u$ ) that prevents DNA binding of ZIC2 protein [15, 16, 26]. The incorrect formation of the anterior notochord results in an arrest of prechordal plate development, most likely because the anterior notochord normally generates a prechordal plate maintenance signal $[26,49]$. The prechordal plate in turn is the site of expression of Sonic Hedgehog $(\mathrm{SHH})$ a secreted molecule that is crucial for patterning the overlying ventral forebrain. If a functioning SHH signal is not produced by the prechordal plate, or not received by the forebrain neuroectoderm, then the developing brain does not separate into the left and right hemispheres, leading to HPE. In the most severe cases of HPE, the formation of the eye field is also affected and can produce two eyes that are abnormally close together (hypotelorism), two eyes that are fused at the midline (synophthalmia), or a single, ventrally displaced eye (cyclopia). Embryos homozygous for the severe loss-of-function $K u$ allele exhibit the full range of ventrally induced HPE phenotypes mimicking the range of ventral forebrain HPE phenotypes (or classical HPE) associated with heterozygous loss-of-function mutation of human ZIC2 [26, 50, 51]. Zic2 is not expressed within the ventral forebrain and it should be noted that despite the fact that the classical forms of HPE are considered defects of forebrain development, the finding of Zic2-associated HPE in $K u / K u$ embryos reveals a role for ZIC2 during gastrulation rather than during forebrain development per se. Zic2 is the only Zic gene expressed in the node of the mid gastrula and it is possible that in Zic2 mutants this is the only tissue at this stage of development in which ZIC2 function is not at least partially rescued by the expression of Zic3 and/or Zic5.

\section{Zic function at patterning and morphogenesis}

Once the germ layers are formed and the three embryonic axes are established, the embryo enters a phase of patterning the newly formed germ layers with respect to the axes and of morphogenesis so that by $9.5 \mathrm{dpc}$ an embryo with the rudiments of almost every organ and system is produced. Zic genes are required to ensure that several aspects of patterning and morphogenesis occur correctly. One of the earliest morphogenetic events during this period is primary neurulation; the process that converts a flat sheet of neuroepithelium into the neural tube. Neural tube closure first requires that the neuroepithelium bends and that the two lateral margins of the neuroepithelium are brought into opposition before fusing at the dorsal midline of the embryo. In the mouse neural tube, closure begins at $8.5 \mathrm{dpc}$ (when the embryo has $\sim$ six somites) and initiates at three different points along the length of the embryo. A failure of closure at the different points results in discrete classes of neural tube defects. For example, a failure of cranial neurulation results in exencephaly, while a delay of trunk closure results in spina bifida. In mouse embryos, a failure to complete the closure of the trunk neural tube at the posterior neuropore before the process of secondary neurulation (which forms the neural tube of the tail region) begins to produce a curled tail [52]. Evidence that Zic gene expression is required for primary neurulation comes from the analysis of phenotypes associated with Zic mutated alleles. This includes an incompletely penetrant curled tail and spina bifida in animals heterozygous for the $\mathrm{Zic} 2 \mathrm{Ku}$ allele $\left(\mathrm{Zic} 2^{\mathrm{Ku} /+}\right.$ ), frequent exencephaly, and delayed posterior neuropore closure in all homozygous $K u$ embryos $Z i c 2^{K u / K u}$ embryos [15], incompletely penetrant exencephaly and delayed posterior neuropore closure in embryos homozygous or hemizygous for either of the Zic3 null alleles $\left(\mathrm{Zic}^{B n}\right.$ or Zic3 $\left.{ }^{\text {TmlBca }}\right)[45,53-56]$ and incompletely penetrant exencephaly in both targeted null alleles of Zic5 (Zic5 $5^{\text {Tm1Jaru }}$ and Zic5 $\left.{ }^{\text {Tm1Sia }}\right)[31,57]$. Molecular investigation of the cause of delayed posterior neuropore closure in Zic $2^{K u / K u}$ embryos suggests that elevated bone morphogenetic protein (BMP) signaling (caused by decreased expression of BMP antagonists) may prevent the formation of the dorsal lateral hinge points required for neural tube closure at rostral levels of the trunk [58].

A process concomitant with, but independent of, neurulation is the formation of the neural crest. The neural crest is a transitory population of cells that arises at the boundary of the neural and non-neural ectoderm [59, 60]. In the mouse, the emigration of the cranial neural crest is complete before cranial neural tube closure ( 18 somites) and trunk crest begins to emerge from the dorsal neural tube at early somite stages and before neural tube closure begins. Although all murine Zic genes are expressed in the dorsal neural tube, only Zic2, Zic3, and Zic5 are expressed in the neuroectoderm at early somite stages when the neural crest is first being formed. There is good evidence that Zic gene expression is required for neural crest generation in the mouse embryo. Loss of Zic2 function results in depletion of neural crest cells at all axial levels [15] and embryos that lack Zic5 produce less cranial neural crest than normal embryos [31]. In the case of loss of Zic2 function, the defect 
has been shown to occur at an early stage of neural crest development, which is likely to reflect the inability of the ZIC2-depleted neuroectoderm to respond to neural crest induction [15].

Additional roles for Zic2 expression in the development of the CNS have been found. Firstly, Zic $2^{K u / K u}$ embryos exhibit a defect in the establishment of the transient segmented structures (rhombomeres) that form within the hindbrain [15]. In addition, embryos homozygous for the hypomorphic Zic ${ }^{K d}$ allele (which was generated via an incorrect targeting event leading to reduced expression of wild-type Zic2 gene product) exhibit defects of the dorsal forebrain [61]. During neural patterning, the specialized roof plate structure forms at the dorsal midline of the neural tube. This region participates in patterning the dorsal-ventral axis of the neuroectoderm and its ablation in mouse embryos leads to a mild, dorsal form of HPE called the middle interhemispheric (MIH) variant [62]. Zic2 $2^{K d / K d}$ embryos lack a morphologically recognizable roof plate and exhibit a phenotype that may correspond to human MIH HPE. In humans, only heterozygous ZIC2 mutations are found, resulting in partial loss-of-function. These mutations are associated with multiple central nervous system defects ranging from classical (alobar) to the milder MIH HPE. The only human ZIC2 variant associated with MIH HPE behaves as a hypomorphic allele in cell-based transcription assays [16] and it seems likely that partial loss of ZIC2 function causes MIH HPE in both mouse and man. Conversely, the Zic $2^{K d / K d}$ mutants do not present with classical HPE and do not have neural crest or hind brain patterning defects, indicating that a small amount of functional ZIC2 protein is sufficient to prevent these phenotypes. The molecular basis of the hindbrain and dorsal forebrain Zic2-associated phenotypes has not been investigated and no other Zic gene mutations have been reported to give a hindbrain patterning phenotype, indicating that the requirement in this process may be Zic2 specific.

Throughout this period of embryogenesis, the mesoderm generated during gastrulation also becomes patterned. The lateral mesoderm which arises from the posterior primitive streak becomes segmented into the somites that give rise to the musculoskeletal system. Heterozygous loss-of-function of either Zic2 or Zic3 genes is sufficient to produce tail kinks caused by dysmorphic vertebrae [15, 63] and animals that have a partial loss of Zic2 function $\left(Z i c 2^{K d / K d}\right)$ or which lack $Z i c 3$ function $\left(Z i c 3^{B n / Y}\right)$ have a decreased number of tail vertebrate, which is exacerbated in $\mathrm{Zic} 2^{\mathrm{Kd} /+} ; \mathrm{Zic} 3^{\mathrm{Bn} / Y}$ animals. These phenotypes indicate a deficit of the precursor cells from which the somites arise and defective somitogenesis. Analysis of somitogenesis in Zic mutant embryos suggests a role in the establishment of somite compartments [64]. These defects are consistent with the expression of Zic2 and $Z i c 3$ in the primitive streak and the emerging lateral mesoderm [32] and in the pre-somitic mesoderm [35]. Defects in the axial skeleton have also been described from loss of Zic5 function but this has not been well studied [64].

\section{Zic function during organogenesis}

Once the embryonic pattern is established, individual tissues begin to differentiate during organogenesis. Mutational analysis has revealed further functions for the Zic genes at these stages in the developing brain, visual system, and in the axial and appendicular skeleton. It is at this stage that the expression of the additional Zicl/4 gene pair begins and roles for these genes have been established in organogenesis.

Either primary or redundant roles for each of the five Zic genes have been described within the developing CNS. There is good evidence that Zicl and Zic4 interact at the genetic level to regulate the development of the hindbrainderived cerebellum, which plays an important role in motor control. Loss of Zicl function alone (Zicl ${ }^{\text {TmIJaru }}$ ) produces morphological abnormalities of the cerebellum (hypoplasia and abnormal foliation), and corresponding behavioral abnormalities (a failure to develop the righting reflex and ataxia) [65, 66]. Animals that lack Zic4 function alone $\left(Z i c 4^{t m 2 K j m i}\right)$ do not display overt cerebellar morphology or behavioral abnormalities, but Zic4 ablation on the Zic1 null background exacerbates the phenotype [66]. Similarly, animals heterozygous null for either Zicl or Zic4 alone have no discernible phenotype, whereas animals heterozygous for a targeted mutation that removes both Zicl and Zic4 function $\left(\right.$ Zicl/Zic $\left.4^{\text {tmlKjmi}}\right)$ have cerebellar abnormalities that mimic the defect of human hindbrain development known as Dandy-Walker malformation (DWM) and a subset of DWM patients are hemizygous for both ZICl and ZIC4 [67]. The reduction in cerebellar size results from decreased proliferation of the granule cell progenitor population, a process that requires SHH signaling. Shh is expressed normally in the developing cerebellum of the mutant embryos, suggesting that ZIC1 and ZIC4 proteins are directly or indirectly required to receive or transduce the $\mathrm{SHH}$ signal. The molecular basis of the abnormal foliation pattern is not known, but SHH signaling is not required for this process [66]. As with Zic2 function in forebrain patterning, this work has revealed sequential, temporally separate and molecularly disparate requirements for $\mathrm{Zicl}$ and $\mathrm{Zic4}$ gene function during cerebellar development. Zic2 has also been shown to play a secondary role in cerebellar function. Zic $2^{K d / K d}$ animals have no cerebellar phenotype, yet one copy of this allele in combination with heterozygous loss of Zicl produces a phenotype similar to the Zicl null allele. It appears that haploinsufficiency for Zicl sensitizes the development of the cerebellum such that minor perturbations in other Zic genes can produce a phenotype similar to that of the Zicl null. This suggests some overlap in function, but that Zicl also has some function that cannot be compensated for by 
Zic4 or Zic2 expression. Animals that are null for Zic3 also exhibit regional hypoplasia of the cerebellum and mild foliation defects demonstrating a non-redundant role of Zic3 in cerebellum development.

Zic5 function has not been implicated in cerebellar development, but Zic5 null mice exhibit subtle forebrain defects including poor differentiation of dorso-medial telencephalic structures, a phenotype that may be analogous to the roof plate defect seen in Zic2 ${ }^{K d / K d}$ embryos [57]. Additionally, several regions of the forebrain are underdeveloped, which corresponds to enlarged forebrain-derived ventricles [57], a feature that may be related to the occasional hydrocephalus documented in homozygous null animals [64]. Hydrocephalus also occurs in a proportion of animals with decreased dosage of Zicl and Zic2 expression ( $\mathrm{Zic1}^{+/-} ; \mathrm{Zic}^{\mathrm{Kd} /+}$ ) [68]. In contrast to Zic5, a role for Zicl, Zic2, and Zic3 function in forebrain development is revealed only when compound mutants are generated [36], suggesting a high level of functional redundancy between the Zic genes during forebrain development. As with the cerebellar phenotypes, where investigated, the forebrain phenotypes are associated with decreased proliferation of neuronal precursor cells, increased exit from the cell cycle, and an increased number of cells expressing markers of differentiated neurons at early stages of neurogenesis. Paradoxically, the early increase in the neuron number culminates in an eventual depletion of neurons and a reduced size of the affected brain region. Apparently Zic genes are required to promote self-renewal of the neuronal precursors to ensure a sufficient number of differentiated neurons. This conclusion is supported by that fact that mis- or over-expression of either Zicl or Zic3 in the developing CNS inhibits neuronal differentiation. The molecular basis of this function is not known and whether ZIC proteins trans-activate cellular proliferation pathways, repress gene expression required for differentiation, or both remains to be determined. It is hypothesized that the Zic genes act via the Notch pathway to exert this influence, but to date this has not been genetically tested.

Zic gene mutation also leads to a variety of largely uncharacterized eye phenotypes. For example, Zic5 null embryos are reported to have occasional microphthalmia or anophthalmia [44] as do Zic2 ${ }^{K d / K d}$ embryos [69]. One well-characterized role in the visual system for Zic genes is the requirement for Zic2 expression to generate ipsilateral projections from retinal ganglion cells. The decision of retinal axons to either cross the midline at the optic chiasm (to project contralaterally) or to avoid the midline (and project ipsilaterally) is essential for binocular vision (high numbers of ipsilateral projections correlate with highly developed binocular vision). Partial loss of Zic2 function is sufficient to reduce $\left(\mathrm{Zic} 2^{K d /+}\right)$ or eliminate $\left(\mathrm{Zic} 2^{K d / K d}\right)$ the ipsilateral projection of retinal ganglion cells, [69], whereas expression of Zic2 in neurons that normally project contralaterally is sufficient to redirect them to an ipsilateral location [70]. Ectopic expression and axon redirection is associated with the upregulation of the EphB1 receptor [70, 71], but some axon redirection occurs when Zic2 is ectopically expressed in EphB1 null embryos, suggesting EPHB1-dependent and -independent mechanisms are involved in ZIC2-driven axon guidance [70, 71].

As alluded to above, the Zic genes play a variety of roles in the development of the somite-derived structures. Each somite initially undergoes a mesenchymal-to-epithelial transition and the epithelium becomes partitioned into the presumptive sclerotome (ventromedial), myotome (dorsomedial), and dermatome (lateral) regions. The sclerotome cells then revert to being mesenchymal, break away from the somite, migrate around the neural tube, and form the major components of the axial skeleton (vertebrae, ribs, and sternum). All three of the ZOC-containing Zic genes are required for this process. Mutation of Zic1, Zic2, or Zic3 alone is sufficient to cause defects in the dorsal part of the vertebrae (the vertebral arches) and in each case analysis precludes an early effect on somite formation implicating a requirement for Zic gene function during the later process of sclerotome differentiation [64, 72]. Animals that lack Zic3 and retain only a small amount of Zic2 function $\left(\mathrm{Zic} 2^{\mathrm{Kd} /+}\right.$; $Z i c 3^{B n / Y}$ ) have defects of the vertebral arches as well as the ventral vertebral bodies, suggesting functional redundancy in the development of ventral vertebral structures [64]. Each of these $\mathrm{Zic}$ genes is also expressed in the dorsomedial myotome, which will give rise to much of the body musculature. Zic2 has been proposed to contribute to expression control of the muscle differentiation gene Myf5 in the mouse myotome [73]. Mutation of $\mathrm{Zic}$ genes has also been reported to give rise to defects of the appendicular skeleton, in particular the distal limb structures. When the $B n$ allele of Zic3 was first isolated, Garber reported some $\mathrm{Zic} 3^{B n / Y}$ animals had malformed forelimbs [74], and recently the targeted null allele of Zic3, while not itself producing limb defects, has been shown to rescue the heterozygous Gli3 loss-of-function phenotype of the extra toes mutant. Gli3 is a transcriptional mediator of the Shh signaling pathway, which acts as an activator or repressor depending upon specific post-translational modifications. It appears that Zic3 can influence the balance of Gli3 activator and repressor forms and therefore promote Shh expression and signaling in the limb bud [75]. Depletion of Zic2 function is associated with defects of the limb skeleton but the molecular basis of this remains unknown [61].

\section{Xenopus zic genes}

Most of the functional studies on the ZIC gene family have been carried out in Xenopus laevis on the orthologous zic genes and zic proteins. The complete removal 
of gene function is difficult in Xenopus; therefore a combination of gene knockdown and overexpression studies has been used to quickly identify phenotypic defects and transcriptional alterations. These experiments have both identified novel roles for the zic gene family and confirmed functions found in other model organisms. Since many of these experimental approaches differed between independent laboratories, the interpretation and comparison of the data has proven difficult, therefore the resultant phenotypes are mostly discussed separately in this review (Table 2).

Since zic2 is maternally expressed in Xenopus laevis, it is difficult to use morpholino-based approaches to identify its function in vivo. Therefore, the host transfer method was used to eliminate maternal zic2 expression by injecting anti-sense oligonucleotides into unfertilized oocytes that were planted back into a mother animal. This method led to phenotypes including exogastrulation, anterior truncations, and axial defects [10, 41]. Although initiation of gastrulation occurred normally, a delay in blastopore closure was evident, in $30 \%$ of the exogastrulae. The other surviving embryos exhibited deep involution of the marginal zone, reduced head size, wrinkled epidermis, and a stunted dorsal axis. Despite the fact that these abnormalities can be due to secondary effects, clear forebrain defects were evident. In addition, neural tube formation and somitogenesis were clearly disrupted. The notochord seemed to be thickened and in some cases duplicated. Analysis of nodal target gene expression revealed a general increase in nodal signaling in these embryos. Injection of the nodal antagonist cerberus short in part rescued the phenotype, indicating indeed that Nodal signaling was disturbed but was not the only signaling pathway affected. This was further confirmed by our group and others when zic2 and other zic proteins were able to repress canonical Wnt signaling [10, 22]. This finding was partially based on injection of $z i c 3$ mRNA that was found to alter the expression of organizer markers including goosecoid and siamois, which are direct Wnt target genes, and impaired notochord development. Due to the possible non-specific nature of this overexpression phenotype, a loss-of-function approach was also used. The injection of zic3 morpholinos alone did not generate obvious abnormalities but co-injection with zic2 morpholinos revealed a clear phenotype. In accordance with the maternal zic2 knockdown phenotype, the notochord was thickened and widened, A-P axis was shortened and the size of head structures were reduced [22]. Although maternal zic2 proteins cannot be directly targeted, targeting of zygotic expression by morpholino technology revealed clear phenotypes attributable to altered zygotic zic2 and zic 3 expression. This again demonstrated the functional redundancy in this gene family. Other early functions associated with zic 3 expression in Xenopus include regulation of left-right $(\mathrm{L}-\mathrm{R})$ patterning and convergent extension (C-E) morphogenesis. Similarly, and as previously mentioned, in humans, ZIC3 mutations result in X-linked heterotaxy, and Zic3 null mice exhibit
Table 2 Xenopus zic gene gainand loss-of-function phenotypes

Summarized are phenotypes occurring in Xenopus embryos injected with zic-specific morpholino or (dominant negative) mRNA

\begin{tabular}{|c|c|c|}
\hline Zic phenotypes & Genotypes & References \\
\hline \multicolumn{3}{|l|}{ Gain-of-function } \\
\hline Organizer dysgenesis & $z i c 3$ & Fujimi et al. [94] \\
\hline Impaired notochord formation & $z i c 3$ & Fujimi et al. [94] \\
\hline $\begin{array}{l}\text { Induced neuroectoderm } \\
\text { formation }\end{array}$ & $z i c 1, z i c 2, z i c 3$ & $\begin{array}{l}\text { Nakata et al. [3, 42, 43], Kuo et al. } \\
\text { [78], Misuzeki et al. [76] }\end{array}$ \\
\hline Neurogenesis inhibition & $z i c 2$ & Brewster et al. [79] \\
\hline Induced neural crest cells & $z i c 1, z i c 2, z i c 3, z i c 4$, and $z i c 5$ & $\begin{array}{l}\text { Nakata et al. }[3,42,43], \\
\text { Fujimi et al. [40] }\end{array}$ \\
\hline Larger head structure & $z i c 1, z i c 2$, and $z i c 3$ & Nakata et al. $[3,43]$ \\
\hline Smaller eyes & $z i c 1, z i c 2$, and $z i c 3$ & Nakata et al. $[3,43]$ \\
\hline Induced retina & $z i c 1, z i c 2$, and $z i c 3$ & Nakata et al. $[3,43]$ \\
\hline \multicolumn{3}{|l|}{ Loss-of-function } \\
\hline $\begin{array}{l}\text { Exo-gastrulation, anterior } \\
\text { truncations, and axial defects }\end{array}$ & Maternal zic2 & Houston et al. [41] \\
\hline $\begin{array}{l}\text { Delay in gastrulation, left-right } \\
\text { patterning, convergent extension } \\
\text { morphogenesis, midline } \\
\text { abnormalities, abnormal heart } \\
\text { and gut looping }\end{array}$ & $z i c 3$ & Cast et al. [47] \\
\hline $\begin{array}{l}\text { Thickened notochord, A-P axis } \\
\text { shortening, and reduced } \\
\text { head structures }\end{array}$ & $z i c 2+z i c 3$ & Fujimi et al. [94] \\
\hline
\end{tabular}


defects in gastrulation, neural tube closure, and axial patterning $[45,48]$. Xenopus zic3 morphants revealed significant impairment of $\mathrm{C}-\mathrm{E}$ and in $\mathrm{L}-\mathrm{R}$ patterning. The A-P axis was shortened, gastrulation was delayed, and abnormal heart and gut looping [47]. Collectively, these data support an evolutionarily conserved role of Zic3 gene function during early vertebrate embryonic development.

At the prospective neural plate region, zic3 was found to be ectopically expressed upon BMP4 signaling blockade. As for other neural inducers, it was postulated that repression of zic3 expression was relieved when neural inducing signals altered BMP4 signaling [3]. Similarly, in addition to $z i c 3, z i c 1$ and $z i c 2$ were shown to be downstream targets of BMP4 signaling. The expression of both genes was upregulated in the neuroectoderm and both were potent inducers of neuroectodermal differentiation, though the potency of induction was less with zicl compared with zic 2 expression [43, 76-78].

Furthermore, zic2 was shown to be expressed in stripes that alternate with those in which primary neurons differentiate in the neuroectoderm, and overlap the domains of floor plate and neural crest progenitors (stage 14). Zic2 overexpression leads to induced neural crest cell differentiation and inhibition of neurogenesis, elevating zic2 to the rank of vertebrate pre-pattern gene. The same expression pattern was found for $z i c 5$ but this was not further investigated [42, 79]. More recent studies indicate, in addition to BMP signaling, $\mathrm{Ca}^{2+}$ accumulation can also regulate zic expression in Xenopus and that BMP signaling blockade together with fibroblast growth factor (FGF) activation triggers zic gene activation to induce neuroectoderm formation [80].

While it has only been demonstrated for $z i c 1$ and $z i c 3$, it appears likely that $z i c 2$ expression is also under control of BMP and FGF signaling. However, mice harboring mutations in both Bmprla and Bmprlb genes, which results in a clear MIH HPE phenotype, maintain Zic2 expression [81], suggesting that BMP is not required for Zic2 expression in this context. Bearing in mind that this signaling cascade is essential for neuroectodermal differentiation, it is however very probable that specific members of the ZIC gene family act through these pathways during normal neural development in these animal models [82-85]. The genetic regulation of Xenopus zic genes is also discussed in more detail in the light of vertebrate neuroectodermal differentiation [80].

Both knockdown and overexpression of zic 3 resulted in clear neuroectodermal defects and lead to disturbed neurulation events. Although it is difficult to determine if the later defects are direct effects of altering zic 3 expression, clear phenotypes arose after ectopic expression. Induced pigmented cells were accompanied by a general expansion of the head structures without mesodermal induction. This does not account for effects in the eyes, which were smaller compared with the wild-type embryos while markers of neural retina were upregulated. Essentially the same characteristics were found when $z i c 1$ and $z i c 2$ were overexpressed, namely a thickening of the neural tube and ectopically expressed pigmented cells. Marker-based analysis revealed that the epidermal cell fate was shifted to neural and neural crest cell fate without changing the expression of mesodermal markers [43].

Primary neurons and hindbrain cells were lost using a morpholino against zicl expression and by injection of a dominant negative zic 5 protein. Also, the induction of neural crest cells was disrupted. Similar defects were shown when XMeis3, a transcription factor that can induce hindbrain cell fates in a non-cell-autonomous manner, was knocked down, while the expression of all zic genes was maintained in this setting. This would suggest a role downstream of zic gene expression for XMeis3 function. This hypothesis was confirmed when the phenotype of the zicl morphant was rescued following co-injection of Xmeis3 [86, 87]. Since Xmeis3 is shown to activate the hindbrain induction center that regulates early A-P cell fate in the developing CNS, its potential loss of activity can directly explain the phenotype in the zicl and zic5 loss-of-function models.

Overexpression of zic5 in Xenopus led to a very strong neural crest cell-induced phenotype. Although zic5 is expressed only from the onset of neural crest cell induction, it induces ectopic melanin-forming cells very efficiently. Marker gene analysis shows that overexpression of zic5 also leads to the epidermal fate switched to neural and neural crest cell fate. A notable difference in the effects from overexpression of the different zic genes are to the anterior neural makers, which are unaffected in zic5 gain-of-function assays while they were disrupted in zicl-3 overexpression models. This would indicate that there are not only structural and expression-based differences, but that zic5 function appears at least in part to have been modified during evolution compared with the zic 1-3 genes [42].

Overexpression of zic4 results in an overlapping phenotype compared with the other zic gene family members. As for all zic genes, melanocyte formation was increased leading to an observed increase in neural crest cell formation. A general induction of neural tissue differentiation was evident, although no anterior neural markers (similar to zic5 overexpression) were altered. Hypoplastic eyes were observed with zic4 overexpression, which did not occur when other zic genes were overexpressed. Since zic4 expression is not observed in the Xenopus normal eye, this could be interpreted as an indirect effect. In general, the zic4 overexpression phenotype largely mimics that observed for $z i c 5$ overexpression leading again to the separation of the family into two groups that can be traced back to the chromosomal duplication where the zic4 and zic5 genes seem to have lost intrinsic characteristics that remain in the zicl, $z i c 2$, and zic3 genes [40]. 


\section{Discussion}

Protein structure and synexpression subfamilies

Current investigations regarding Zic gene structure, expression, and function lead to an emerging picture in which gene duplication followed by loss of conserved protein domains and some alteration in expression control mechanisms has resulted in overlapping and unique functions of the orthologous and paralogous Zic family members. The most parsimonious chain of events would be that early in the vertebrate lineage, following an initial tandem gene duplication event, one copy of the tandem gene pair underwent structural changes that include loss of the ZOC motif and alteration in the amino acid composition of the first zinc finger. The subsequent genome duplications of the early vertebrate lineage therefore established two subclasses of Zic proteins. Here we define structural subclass A proteins as those that possess the ZOC motif and have retained sequence conservation across the first zinc finger (ZF1). Structural subclass B proteins are those that lack the ZOC motif and have a diverged amino acid composition of the residues immediately following the tryptophan residue of zinc finger 1. The ZOC motif is implicated in protein/protein interactions and it may therefore be anticipated that the structural subclass A Zic proteins (Zic1, 2, and 3) have some protein partners (and functions) in common but not shared by the structural subclass B proteins (Zic4 and 5). In contrast, the DNA binding ability of the Zic proteins is usually attributed to the more conserved zinc fingers (ZF35), suggesting that all five Zic proteins likely bind the same DNA sequences perhaps with varying affinity. Where investigated, this seems to be the case $[11,88]$.

This structural subclasses division persists amongst orthologous genes but there are some structural features of the Zic proteins that have undergone more rapid divergence such that differences can now be found between orthologs. This is exemplified by the location and composition of the low-complexity regions found outside of the ZOC,
ZF-NC, and zinc finger domains, which can vary remarkably amongst orthologous genes (Fig. 5). Expansion mutations of the c-terminal alanine tract in ZIC2 have been associated with HPE in humans, a congenital defect known to be caused by ZIC2 loss-of-function, suggesting functional significance of this domain. An alanine repeat is found at a similar region in murine Zic2 but not in Xenopus zic2. The precise function of low-complexity regions in the Zic proteins and in general is not well characterized, but there is evidence that they are associated with protein-binding activity and that their position within a sequence may determine their binding properties and biological function [89]. Differences between the sequences of orthologs should be taken into consideration when interpreting data from apparently analogous experiments in different organisms.

The finding that the genomic arrangement of the Zic genes, primarily as bigenes, has been conserved over large evolutionary differences suggests it may have functional significance. In particular it is possible that the bigenes share regulatory regions. A corollary of this hypothesis is that the expression pattern of bigene members would be more similar to one another than to the other paralogs. It remains difficult to determine whether this is the case for practical and technical reasons. First, there are few biological systems where the expression of all five genes has been investigated in detail and, second the hybridization efficiency of the probes used to detect different $Z i c$ mRNA species via in situ hybridization varies. In particular, both Zic4 and Zic5 transcripts seem difficult to detect (i.e., they lead to low signal; see for example Zic5 signal in Fig. 4) using this technique. In order to complete surveys of Zic gene expression, it may be necessary to develop better probes or protocols for the in situ detection of Zic4 and Zic5 transcripts or to augment mRNA localization studies with additional techniques such as RT-PCR or to develop Zic isoform specific antibodies suitable for tissue hybridization studies.

Despite these caveats, the currently available data can be interrogated to assess the evidence for bigene co-expression. In Xenopus it appears that zic2 and zic5 are often
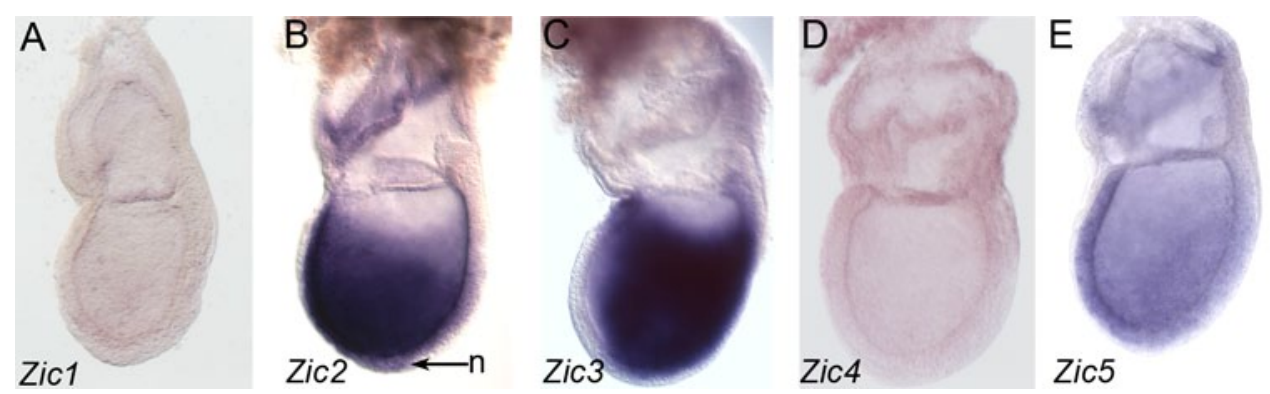

Fig. 4 Co-expression of the murine Zic genes during mouse gastrulation. Lateral view of $7.5 \mathrm{dpc}$ mouse embryos following whole-mount in situ hybridization to Zicl- 5 (anterior is to the left). Zicl and Zic4 are not expressed whereas Zic2, Zic3, and Zic5 are all expressed in the ectoderm and mesoderm of the embryonic region and Zic2 is uniquely expressed in the node of the embryo. $n$ node 

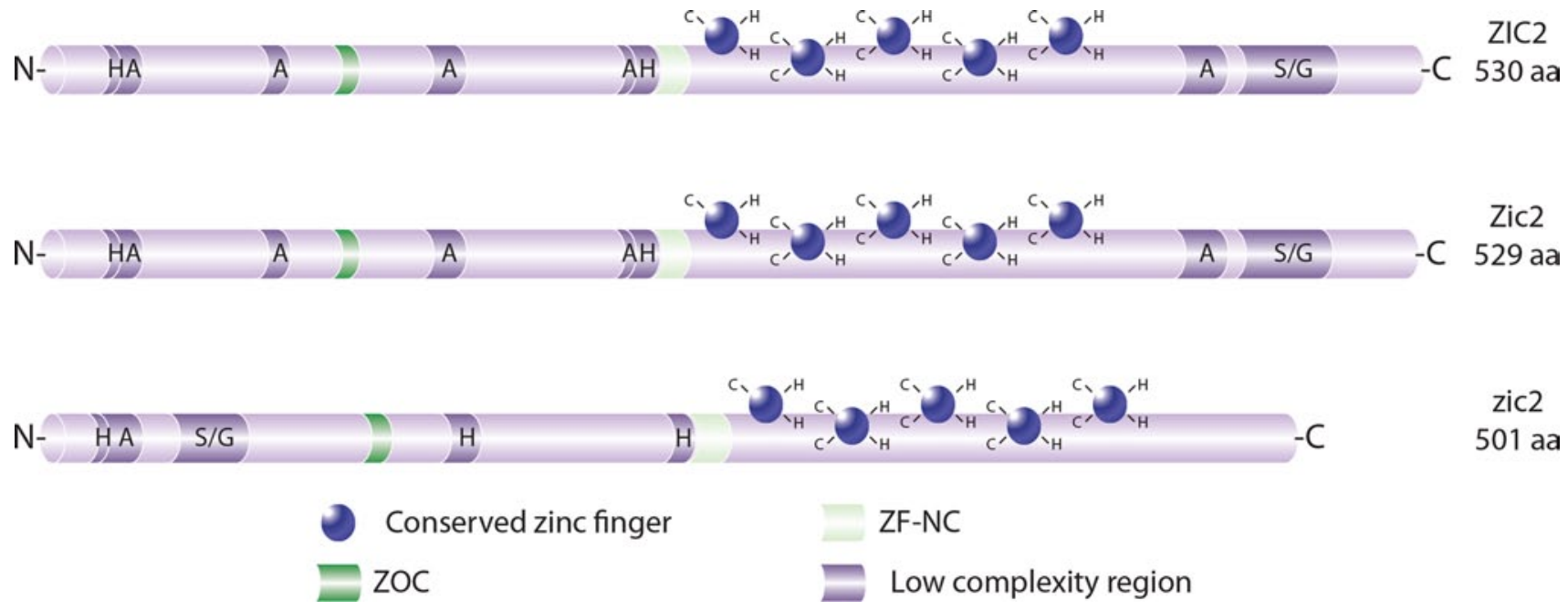

Fig. 5 The continued evolution of low-complexity regions in the vertebrate Zic genes. The ZIC2 protein from three species is depicted. The human (ZIC2) and mouse (Zic2) proteins are near identical with respect to the location, size, and amino acid involved in the depicted low-complexity regions. The Xenopus protein (zic2) differs in each of

co-expressed (in the oocyte, the prospective neural tissue of the gastrula and subsequently at the neural plate border and in the developing retina), but uncoupled expression can also be found. For example, in the neurula, zic2 expression is found along the axis, whereas zic5 expression is restricted to the anterior neural ridge and zic2, but not zic5, is detected in the somites. Similarly, there are many sites at which both zicl and zic4 are expressed (the branchial arches and the somites) but also sites at which zicl alone is detected (notably zic4 expression initiates later than all other Zic genes being first detected in the prospective neuroectoderm of the mid-gastrula). The uncoupled $z i c 3$ gene has elements in common with and unique from the bigene pair expression patterns. It seems possible that in Xenopus the bigenes do share regulatory elements but further studies are needed, for example to confirm whether some sites of zic4 and zic5 expression are currently undocumented.

In contrast to the situation in Xenopus, it seems clear from the murine expression studies that in the mouse the Zic genes can be divided into two synexpression groups with the Zicl/4 bigene forming a distinct group from that of the Zic2/5 bigene and the Zic 3 gene. Notably, this division mirrors the genomic arrangement rather than the structural subclass division of the Zic genes (Fig. 6). In general, during mouse development, the regions where Zicl and 4 are expressed are sites where all five Zic family members are transcribed. In contrast, there are several sites where only Zic2, 3, and 5 are expressed (such as during gastrulation, in the presomitic mesoderm and developing limb bud). The pattern of expression therefore seems different from that in Xenopus where, for example, at least one member of the these respects; note in particular the absence of the C-terminal alanine and serine/glycine tracts. The major amino acid found at each low-complexity region is shown by the associated letter ( $A$ alanine, $H$ histidine, $S / G$ serine/glycine)

zicl/4 bigene is expressed during gastrulation. This suggests that some Zic gene regulatory mechanisms have been significantly altered between Xenopus and the mouse, perhaps by the loss or gain of entire enhancers, rather than by the alteration of transcription binding sites within a conserved enhancer [25]. This raises the question of where the ZIC genes are expressed during human embryonic development. The strong correlation between loss-of-function phenotypes in mouse and man and the conserved genomic arrangement suggests that the expression patterns in human likely resemble those of the mouse.

Non-redundant and redundant function

In some cases, the inactivation of individual Zic genes can produce unique phenotypes (i.e., phenotypes not seen when other family members are alone mutated). Human and mouse genetics demonstrates that phenotypes in this category include ZIC2-associated classical HPE and ZIC3associated heterotaxy indicating that the function of ZIC2 and ZIC3 in these processes is not fully redundant. This lack of redundancy may be caused a lack of co-expression. In this case, the unique phenotypes found upon individual Zic gene inactivation would reveal sites where only one Zic gene is expressed with the function of the missing member being fully compensated for (i.e., redundant) in areas of Zic gene co-expression. This idea is exemplified by the association between ZIC2 mutation and classical HPE, which has been examined by analysis of the $K u$ mouse mutant. In this case, the first overt molecular defect found in $\mathrm{Zic} 2^{\mathrm{Ku} / \mathrm{Ku}}$ embryos is at the mid-gastrula node, a structure required 


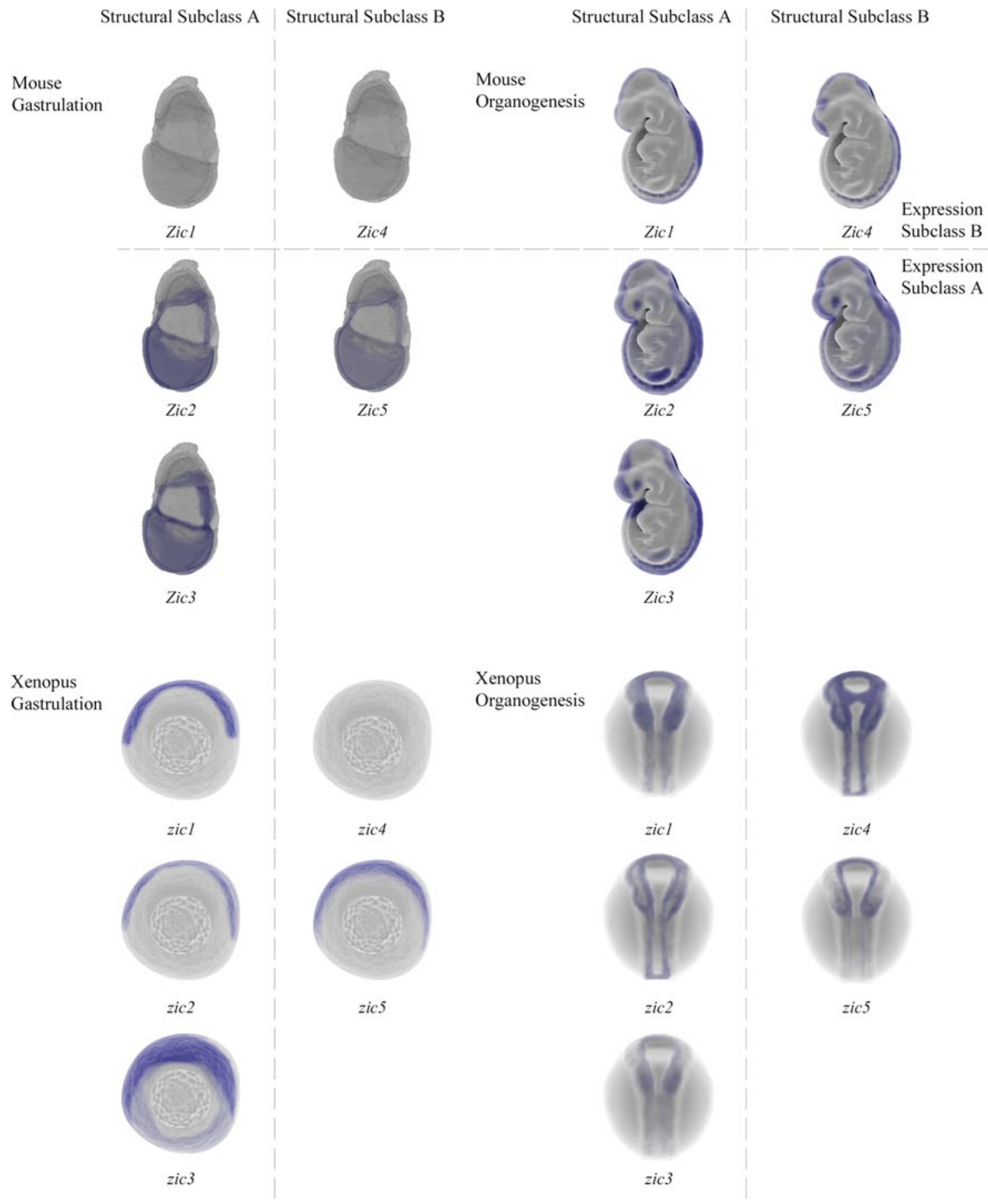

Fig. 6 The murine Zic gene expression subclasses reflect their genomic arrangement. The analysis of the mRNA expression patterns of the murine and Xenopus Zic genes reviewed here are depicted on images of mouse and Xenopus embryos at the stages shown. The data suggest that a new expression subclass has arisen during vertebrate evolution. All Zic genes are expressed in the ectoderm and mesoderm and tissues arising from these germ layers. In the mouse, two clear groups of gene expression patterns are seen; the Expression subclass

A genes are expressed prior to and throughout gastrulation, during neurulation, and in organogenesis. The expression of the subclass $B$ genes does not initiate until after neurulation and is absent from the optic cup, the forelimb bud and pre-somitic mesoderm at early organogenesis. In Xenopus, it seems most likely that there is only one synexpression group with the expression of all five Zic genes initiating prior to or during gastrulation and continuing in some developing central nervous system and mesoderm structures 
for the development of the prechordal plate, the function of which is essential to prevent HPE [26]. This localized defect belies the widespread expression of Zic2 transcripts at preand mid-gastrula stages, which a priori may be expected to cause widespread molecular defects. Zic2 is, however, the only Zic gene expressed at the node with both Zic5 and/or Zic3 sharing other sites of Zic2 expression at these developmental stages $([32,33]$ and Fig. 4). It remains to be tested whether ablation of Zic3 or Zic5 on the Ku mutant background would reveal the additional defects expected if functional redundancy, coupled with a site of Zic2-specific expression, has produced an unusually mild defect in the Zic2 mutant embryos.

In contrast to the HPE phenotype, the Zic gene murine mutational analysis suggests there are sites of full or partial Zic gene redundancy. Full functional redundancy is demonstrated when single mutants have no phenotype but the double mutant does, whereas partial redundancy is said to occur when one or both of the single mutants exhibits a phenotype that is enhanced in the double mutant. Care must be taken when performing and interpreting double mutant analyses since differences in genetic background and the use of hypomorphic alleles are both factors that can confound these experiments. Despite these caveats, there seems good evidence that the Zic genes do in some cases exhibit functional redundancy with one of the best characterized examples being the partial redundancy between Zicl and Zic4 during cerebellum development [66, 67]. Here, null mutation of Zicl is associated with small size and abnormal foliation of the cerebellum. Although animals null for Zic4 exhibit no detectable cerebellar phenotype the size and foliation defects are enhanced (relative to the Zicl null) in the double mutant. Moreover, trans-heterozygous loss of both ZICI and ZIC4 leads to cerebellar size and foliation defects in both man and mouse. This type of non-allelic non-complementation can occur when the two genes involved are both redundant and dose-dependent [90]. This combined haploinsufficiency implies that the amalgamated gene products fall below a threshold level necessary to achieve the wild-type phenotype and is consistent with a situation in which the expression or activity of the paralogs depends upon each other's expression. Here the null mutation in one or both of the genes causes decreased activity of the other leading to apparent haploinsufficiency.

The function of redundant family members can also be investigated by gain-of-function approaches, a strategy well suited to Xenopus embryos. All Xenopus zic family members are expressed at the neural plate border that forms the dorsal part of the neural tube and is the site of differentiation of the neural crest. The overexpression of each zic gene leads to the expansion of neural crest marker gene expression but not to any changes in expression of dorsal mesodermal markers. This highlights the ability of zic gene expression to induce anterior neural tissue and neural crest formation. In contrast with other zic genes, zic4 and zic5 were unable to induce the expression of forebrain and cement gland markers. It is interesting that this apparent functional difference mirrors the structural subclass divisions and suggests for example that the ability of zicl-3 to induce anterior markers may be dependent upon the ZOC motif.

The Zic proteins are multi-functional

Several features of Zic gene genetics suggest that they are multi-functional proteins. Firstly, some Zic genes are required for multiple steps of the development of a particular organ as exemplified by the role of Zic2 in dorsal-ventral forebrain patterning, by Zicl and 4 in cerebellar development and by Zic2 and 3 in skeletal development. Although iterative function is a feature of many developmental proteins, the frequency of Zic gene re-use appears remarkable and is consistent with a multi-functional protein. Secondly, many transcription factors act in response to one particular signaling pathway, for example the Gli transcription factors are mediators of hedgehog signaling and the Lef/Tcf proteins are mediators of Wnt signals. In these cases, mutation of the transcription factors produces similar phenotypes to (or phenocopies) loss-of-function mutations in other pathway members such as receptors and ligands. One factor that has obscured the role of the Zic proteins is that they fail to phenocopy mutations in a particular signaling pathway and instead generally exhibit phenotypes reminiscent of a variety of signaling pathways. Additionally, Zic function is required for a myriad of biological processes and different signaling pathways are dominant in the respective biological processes. Zic gene genetics therefore suggest that the family members interact with many of the key embryonic signaling pathways and in doing so may serve to integrate and balance multiple signaling pathways. This idea is supported by biochemical experiments that demonstrate protein/protein interactions between Zic proteins and key transcriptional mediators of both the Shh and Wnt signaling pathways. These interactions appear to alter the way the pathway specific member can act, for example Zic proteins convert the Tcf transcription factors to repressors and Zic proteins can alter Gli3 repressor function [10, 23, 91].

As reviewed by Ali et al. [14] the molecular basis of Zic protein pleiotropy is beginning to be understood. The Zic genes have previously been shown to display phenotypes that result from the loss of DNA binding activity $[16,26]$, thus establishing that they can act as classical transcription factors. Consistent with this, the same consensus Zic DNA binding motif has now been identified by both a ChIP/Chip experiment and the UNIPROBE experiment $[92,93]$. Biochemical experiments have shown that Zic proteins can also act as transcription co-factors to influence transcription of 
target genes without contacting DNA. In particular, they can physically interact with TCF transcription factors to inhibit Wnt signaling $[10,94]$ and they can also regulate Gli transcriptional activity independent of DNA binding [95]. In addition to the established ability of Zic proteins to act as transcription factors and co-factors, the expansion of the Zic gene family provides the opportunity for homo or hetero dimerization and/or dominant negative interactions between the Zic proteins and these possibilities are yet to be fully explored.

Promoting pluripotency: a unifying Zic function?

Despite our inability to link the Zic proteins with one particular signaling pathway or even one class of protein function, can a consistent biological function be found for the Zic proteins? The reason behind many of the described Zicassociated phenotypes has not been fully investigated. One function that has been ascribed to the Zic genes multiple times is that of promoting pluripotency. Zic mutant endphenotypes are often associated with small size (of the affected organ or of the entire animal). Where investigated, the reduced size has been attributed to the premature differentiation of a progenitor population. This has the effect of ultimately decreasing the size of the organ since the progenitor differentiation occurs at the cost of increasing the size of the progenitor pool via self-renewal. Investigations in murine ES cells have also ascribed the task of promoting pluripotency to Zic3 $[96,97]$ and it may be that functional redundancy has obscured this role during early embryogenesis in murine Zic mutants. Although a proportion of Zic-associated phenotypes can be explained by a failure of self-renewal, not all can be; for example, in the case of the Zic2-associated neural crest cell defect it is the number of differentiated cells that is depleted, not the progenitor pool. Clearly, the Zic family members are involved in differentiation as well as the control of pluripotency. Further work is needed to determine whether many of the Zic-associated phenotypes are caused by altered fate, renewal, or other cellular properties.

\section{Conclusions}

We conclude that the Zic genes encode proteins that truly are partially redundant, multi-functional molecules that operate in a context-specific manner to drive a large number of critical events during embryogenesis. Their ancestral role in the generation of neuroectoderm and mesoderm-derived tissues seems to have been largely conserved but specific details have been altered through evolution. Our comparison here has revealed differences in protein structure, genomic arrangement, and gene expression patterns between Xenopus and mouse. These differences may explain variation in the outcome of apparently equivalent loss-of-function and gain-of-function experiments between these two organisms. They can also be used to inform ongoing investigations regarding the molecular mechanism of Zic function.

Acknowledgments Prof. Sabine Tejpar is senior investigator of the fund for Scientific Research-Flanders, Belgium (Fonds Wetenschappelijk Onderzoek-Vlaanderen). Rob Houtmeyers is supported by a $\mathrm{PhD}$ grant from the Institute for the Promotion of Innovation through Science and Technology in Flanders (IWT-Vlaanderen).

The templates in Fig. 6 were rendered from the EMAGE gene expression database (http://www.emouseatlas.org/emage/); EMA: 17 (TS11) and EMA:36 (TS15) [99].

\section{References}

1. Aruga J, Yokota N, Hashimoto M, Furuichi T, Fukuda M, Mikoshiba K (1994) A novel zinc finger protein, zic, is involved in neurogenesis, especially in the cell lineage of cerebellar granule cells. J Neurochem 63:1880-1890

2. Aruga J, Nagai T, Tokuyama T, Hayashizaki Y, Okazaki Y, Chapman V, Mikoshiba K (1996) The mouse Zic gene family. Biol Chem 271:1043-1047

3. Nakata K, Nagai T, Aruga J, Mikoshiba K (1997) Xenopus Zic3, a primary regulator both in neural and neural crest development. Proc Natl Acad Sci USA 94:11980-11985

4. Rohr K, Schulte-Merker S, Tautz D (1999) Zebrafish zic1 expression in brain and somites is affected by BMP and Hedgehog signalling. Mech Dev 85:147-159

5. Satou Y, Yagi K, Imai K, Yamada L, Nishida H, Satoh N (2002) macho-1-related genes in Ciona embryos. Dev Genes Evol 212: $87-92$

6. Aruga J, Kamiya A, Takahashi H, Fujimi TJ, Shimizu Y, Ohkawa K, Yazawa S, Umesono Y, Noguchi H, Shimizu T, Saitou N, Mikoshiba K, Sakaki Y, Agata K, Toyoda A (2006) A wide-range phylogenetic analysis of Zic proteins: implications for correlations between protein structure conservation and body plan complexity. Genomics 87:783-792

7. Layden MJ, Meyer NP, Pang K, Seaver EC, Martindale MQ (2010) Expression and phylogenetic analysis of the zic gene family in the evolution and development of metazoans. Evodevo $1: 12$

8. Salero E, Pérez-Sen R, Aruga J, Giménez C, Zafra F (2001) Transcription factors Zic1 and Zic2 bind and transactivate the apolipoprotein E gene promoter. J Biol Chem 19:1881-1888

9. Lim LS, Hong FH, Kunarso G, Stanton LW (2010) The pluripotency regulator $\mathrm{Zic} 3$ is a direct activator of the Nanog promoter in ESCs. Stem Cells 28:1961-1969

10. Pourebrahim R, Houtmeyers R, Ghogomu S, Janssens S, Thelie A, Tran HT, Langenberg T, Vleminckx K, Bellefroid E, Cassiman JJ, Tejpar S (2011) Transcription factor Zic2 inhibits Wnt/betacatenin protein signaling. J Biol Chem 286:37732-37740

11. Mizugishi K, Aruga J, Nakata K, Mikoshiba K (2001) Molecular properties of Zic proteins as transcriptional regulators and their relationship to GLI proteins. J Biol Chem 276:2180-2188

12. Hatayama M, Tomizawa $T$, Sakai-Kato K, Bouvagnet $P$, Kose S, Imamoto N, Yokoyama S, Utsunomiya-Tate N, Mikoshiba K, Kigawa T, Aruga J (2008) Functional and structural basis of the nuclear localization signal in the ZIC3 zinc finger domain. Hum Mol Genet 17:3459-3473

13. Bedard JE, Haaning AM, Ware SM (2012) Identification of a novel ZIC3 isoform and mutation screening in patients with heterotaxy and congenital heart disease. PLoS ONE 6:23755 
14. Ali RG, Bellchambers H, Arkell RM (2012) Zinc fingers of the cerebellum (Zic): transcription factors and co-factors. Int. J Biochem Cell Biol (ahead of publication)

15. Elms P, Siggers P, Napper D, Greenfield A, Arkell R (2003) Zic2 is required for neural crest formation and hindbrain patterning during mouse development. Dev Biol 264:391-406

16. Brown L, Paraso M, Arkell R, Brown S (2005) In vitro analysis of partial loss-of-function ZIC2 mutations in holoprosencephaly: alanine tract expansion modulates DNA binding and transactivation. Hum Mol Genet 14:411-420

17. Hatayama M, Aruga J (2010) Characterization of the tandem CWCH2 sequence motif: a hallmark of inter-zinc finger interactions. BMC Evol Biol 10:53

18. Chhin B, Hatayama M, Bozon D, Ogawa M, Schön P, Tohmonda T, Sassolas F, Aruga J, Valard AG, Chen SC, Bouvagnet P (2007) Elucidation of penetrance variability of a ZIC3 mutation in a family with complex heart defects and functional analysis of ZIC3 mutations in the first zinc finger domain. Hum Mutat 28:563-570

19. Mizugishi K, Hatayama M, Tohmonda T, Ogawa M, Inoue T, Mikoshiba K, Aruga J (2004) Myogenic repressor I-mfa interferes with the function of Zic family proteins. Biochem Biophys Res Commun 320:233-240

20. Brown LY, Odent S, David V, Blayau M, Apacik C, Delgado MA, Hall BD, Reynolds JF, Sommer A, Wieczorek D, Brown SA, Muenke M (2001) Holoprosencephaly due to mutations in ZIC2: alanine tract expansion mutations may be caused by parental somatic recombination. Hum Mol Genet 10:791-796

21. Wessels MW, Kuchinka B, Heydanus R, Smit BJ, Dooijes D, de Krijger RR, Lequin MH, de Jong EM, Husen M, Willems PJ, Casey B (2010) Polyalanine expansion in the ZIC3 gene leading to X-linked heterotaxy with VACTERL association: a new polyalanine disorder? J Med Genet 47:351-355

22. Fujimi TJ, Hatayama M, Aruga J (2012) Xenopus Zic3 controls notochord and organizer development through suppression of the Wnt/beta-catenin signaling pathway. Dev Biol 361:220-231

23. Koyabu Y, Nakata K, Mizugishi K, Aruga J, Mikoshiba K (2001) Physical and functional interactions between Zic and Gli proteins. J Biol Chem 276:6889-6892

24. Keller MJ, Chitnis AB (2007) Insights into the evolutionary history of the vertebrate zic3 locus from a teleost-specific zic6 gene in the zebrafish, Danio rerio. Dev Genes Evol 217:541-547

25. Nyholm MK, Wu SF, Dorsky RI, Grinblat Y (2007) The zebrafish zic2a-zic5 gene pair acts downstream of canonical Wnt signaling to control cell proliferation in the developing tectum. Development 134:735-746

26. Warr N, Powles-Glover N, Chappell A, Robson J, Norris D, Arkell RM (2008) Zic2-associated holoprosencephaly is caused by a transient defect in the organizer region during gastrulation. Hum Mol Genet 17:2986-2996

27. Merzdorf CS (2007) Emerging roles for zic genes in early development. Dev Dyn 236:922-940

28. Grinberg I, Millen KJ (2005) The ZIC gene family in development and disease. Clin Genet 67:290-296

29. Aruga J (2004) The role of Zic genes in neural development. Mol Cell Neurosci 26:205-221

30. Brown L, Brown S (2009) Zic2 is expressed in pluripotent cells in the blastocyst and adult brain expression overlaps with makers of neurogenesis. Gene Expr Patterns 9:43-49

31. Inoue T, Hatayama M, Tohmonda T, Itohara S, Aruga J, Mikoshiba K (2004) Mouse Zic5 deficiency results in neural tube defects and hypoplasia of cephalic neural crest derivatives. Dev Biol 270:146-162

32. Elms P, Scurry A, Davies J, Willoughby C, Hacker T, Bogani D, Arkell R (2004) Overlapping and distinct expression domains of Zic2 and Zic3 during mouse gastrulation. Gene Expr Patterns 4:505-511
33. Furushima K, Murata T, Matsuo I, Aizawa S (2000) A new murine zinc finger gene, Opr. Mech Dev 98:161-164

34. Nagai T, Aruga J, Takada S, Gunther T, Sporle R, Schughart K, Mikoshiba K (1997) The expression of the mouse Zic1, Zic2, and Zic3 gene suggests an essential role for Zic genes in body pattern formation. Dev Biol 182:299-313

35. Gaston-Massuet C, Henderson DJ, Greene ND, Copp AJ (2005) $\mathrm{Zic} 4$, a zinc-finger transcription factor, is expressed in the developing mouse nervous system. Dev Dyn 233:1110-1115

36. Inoue T, Ogawa M, Mikoshiba K, Aruga J (2008) Zic deficiency in the cortical marginal zone and meninges results in cortical lamination defects resembling those in type II lissencephaly. J Neurosci 28:4712-4725

37. Watabe Y, Baba Y, Nakauchi H, Mizota A, Watanabe S (2012) The role of Zic family zinc finger transcription factors in the proliferation and differentiation of retinal progenitor cells. Biochem Biophys Res Commun 415:42-47

38. Toyama R, Gomez DM, Mana MD, Dawid IB (2004) Sequence relationships and expression patterns of zebrafish zic2 and zic5 genes. Gene Expr Patterns 4:345-350

39. Zhang J, Jin Z, Bao ZZ (2004) Disruption of gradient expression of Zic3 resulted in abnormal intra-retinal axon projection. Development 131:1553-1562

40. Fujimi TJ, Mikoshiba K, Aruga J (2006) Xenopus Zic4: conservation and diversification of expression profiles and protein function among the Xenopus Zic family. Dev Dyn 235:3379-3386

41. Houston DW, Wylie C (2005) Maternal Xenopus Zic2 negatively regulates nodal-related gene expression during anteroposterior patterning. Development 132:4845-4855

42. Nakata K, Koyabu Y, Aruga J, Mikoshiba K (2000) A novel member of the Xenopus Zic family, Zic5, mediates neural crest development. Mech Dev 99:83-91

43. Nakata K, Nagai T, Aruga J, Mikoshiba K (1998) Xenopus Zic family and its role in neural and neural crest development. Mech Dev 75:43-51

44. Klootwijk R, Franke B, van der Zee CE, de Boer RT, Wilms W, Hol FA, Mariman EC (2000) A deletion encompassing Zic3 in bent tail, a mouse model for X-linked neural tube defects. Hum Mol Genet 9:1615-1622

45. Purandare SM, Ware SM, Kwan KM, Gebbia M, Bassi MT, Deng JM, Vogel H, Behringer RR, Belmont JW, Casey B (2002) A complex syndrome of left-right axis, central nervous system and axial skeleton defects in Zic3 mutant mice. Development 129:2293-2302

46. Ware SM, Harutyunyan KG, Belmont JW (2006) Zic3 is critical for early embryonic patterning during gastrulation. Dev Dyn 235:776-785

47. Cast AE, Gao C, Amack JD, Ware SM (2012) An essential and highly conserved role for Zic3 in left-right patterning, gastrulation and convergent extension morphogenesis. Dev Biol 364:22-31

48. Ware SM, Harutyunyan KG, Belmont JW (2006) Heart defects in X-linked heterotaxy: evidence for a genetic interaction of Zic3 with the nodal signaling pathway. Dev Dyn 235:1631-1637

49. Arkell RM, Tam PP (2012) Initiating head development in mouse embryos: integrating signalling and transcriptional activity. Open Biol 2:120030

50. Dubourg C, Bendavid C, Pasquier L, Henry C, Odent S, David V (2007) Holoprosencephaly. Orphanet J Rare Dis 2:8

51. Roessler E, Lacbawan F, Dubourg C, Paulussen A, Herbergs J, Hehr U, Bendavid C, Zhou N, Ouspenskaia M, Bale S, Odent S, David V, Muenke M (2009) The full spectrum of holoprosencephaly-associated mutations within the ZIC2 gene in humans predicts loss-of-function as the predominant disease mechanism. Hum Mutat 30:E541-E554

52. Gruneberg H (1955) Heterosis and variability in the mouse. Proc R Soc Lond B Biol Sci 144:220-221 
53. Franke B, Klootwijk R, Lemmers B, de Kovel CG, SteegersTheunissen RP, Mariman EC (2003) Phenotype of the neural tube defect mouse model bent tail is not sensitive to maternal folinic acid, myo-inositol, or zinc supplementation. Birth Defects Res A Clin Mol Teratol 67:979-984

54. Chung B, Shaffer LG, Keating S, Johnson J, Casey B, Chitayat D (2011) From VACTERL-H to heterotaxy: variable expressivity of ZIC3-related disorders. Am J Med Genet A 155A:1123-1128

55. Carrel T, Purandare SM, Harrison W, Elder F, Fox T, Casey B, Herman GE (2000) The X-linked mouse mutation Bent tail is associated with a deletion of the Zic3 locus. Hum Mol Genet 9:1937-1942

56. Klootwijk R, Schijvenaars MM, Mariman EC, Franke B (2004) Further characterization of the genetic defect of the Bent tail mouse, a mouse model for human neural tube defects. Birth Defects Res A Clin Mol Teratol 70:880-884

57. Furushima K, Murata T, Kiyonari H, Aizawa S (2005) Characterization of $\mathrm{Opr}$ deficiency in mouse brain: subtle defects in dorsomedial telencephalon and medioventral forebrain. Dev Dyn 232:1056-1061

58. Ybot-Gonzalez P, Gaston-Massuet C, Girdler G, Klingensmith J, Arkell R, Greene ND, Copp AJ (2007) Neural plate morphogenesis during mouse neurulation is regulated by antagonism of Bmp signalling. Development 134:3203-3211

59. Chan WY, Tam PP (1988) A morphological and experimental study of the mesencephalic neural crest cells in the mouse embryo using wheat germ agglutinin-gold conjugate as the cell marker. Development 102:427-442

60. Sela-Donenfeld D, Kalcheim C (1999) Regulation of the onset of neural crest migration by coordinated activity of BMP4 and Noggin in the dorsal neural tube. Development 126:4749-4762

61. Nagai T, Aruga J, Minowa O, Sugimoto T, Ohno Y, Noda T, Mikoshiba K (2000) Zic2 regulates the kinetics of neurulation. Proc Natl Acad Sci USA 97:1618-1623

62. Cheng X, Hsu CM, Currle DS, Hu JS, Barkovich AJ, Monuki ES (2006) Central roles of the roof plate in telencephalic development and holoprosencephaly. J Neurosci 26:7640-7649

63. Gruneberg H (1963) The pathology of development, a study of inherited skeletal disorders in animals. Wiley, New York

64. Inoue $\mathrm{T}$, Ota M, Mikoshiba K, Aruga J (2007) Zic2 and Zic3 synergistically control neurulation and segmentation of paraxial mesoderm in mouse embryo. Dev Biol 306:669-684

65. Aruga J, Minowa O, Yaginuma H, Kuno J, Nagai T, Noda T, Mikoshiba K (1998) Mouse Zic1 is involved in cerebellar development. J Neurosci 18:284-293

66. Blank MC, Grinberg I, Aryee E, Laliberte C, Chizhikov VV, Henkelman RM, Millen KJ (2011) Multiple developmental programs are altered by loss of Zic1 and Zic4 to cause Dandy-Walker malformation cerebellar pathogenesis. Development 138:1207-1216

67. Grinberg I, Northrup H, Ardinger H, Prasad C, Dobyns WB, Millen KJ (2004) Heterozygous deletion of the linked genes ZIC1 and ZIC4 is involved in Dandy-Walker malformation. Nat Genet 36:1053-1055

68. Ogura H, Aruga J, Mikoshiba K (2001) Behavioral abnormalities of Zic1 and Zic2 mutant mice: implications as models for human neurological disorders. Behav Genet 31:317-324

69. Herrera E, Brown L, Aruga J, Rachel RA, Dolen G, Mikoshiba K, Brown S, Mason CA (2003) Zic2 patterns binocular vision by specifying the uncrossed retinal projection. Cell 114:545-557

70. Garcia-Frigola C, Carreres MI, Vegar C, Mason C, Herrera E (2008) Zic2 promotes axonal divergence at the optic chiasm midline by EphB1-dependent and -independent mechanisms. Development 135:1833-1841

71. Lee R, Petros TJ, Mason CA (2008) Zic2 regulates retinal ganglion cell axon avoidance of ephrinB2 through inducing expression of the guidance receptor EphB1. J Neurosci 28:5910-5919
72. Aruga J, Mizugishi K, Koseki H, Imai K, Balling R, Noda T, Mikoshiba K (1999) Zic1 regulates the patterning of vertebral arches in cooperation with Gli3. Mech Dev 89:141-150

73. Pan H, Gustafsson MK, Aruga J, Tiedken JJ, Chen JC, Emerson CP Jr (2011) A role for Zic1 and Zic2 in Myf5 regulation and somite myogenesis. Dev Biol 351:120-127

74. Garber ED (1952) "Bent-Tail," a dominant, sex-linked mutation in the mouse. Proc Natl Acad Sci USA 38:876-879

75. Quinn ME, Haaning A, Ware SM (2012) Preaxial polydactyly caused by Gli3 haploinsufficiency is rescued by Zic3 loss of function in mice. Hum Mol Genet 21:1888-1896

76. Mizuseki K, Kishi M, Matsui M, Nakanishi S, Sasai Y (1998) Xenopus Zic-related-1 and Sox-2, two factors induced by chordin, have distinct activities in the initiation of neural induction. Development 125:579-587

77. Mizuseki K, Kishi M, Shiota K, Nakanishi S, Sasai Y (1998) SoxD: an essential mediator of induction of anterior neural tissues in Xenopus embryos. Neuron 21:77-85

78. Kuo JS, Patel M, Gamse J, Merzdorf C, Liu X, Apekin V, Sive H (1998) Opl: a zinc finger protein that regulates neural determination and patterning in Xenopus. Development 125:2867-2882

79. Brewster R, Lee J, Ruiz i Altaba A (1998) Gli/Zic factors pattern the neural plate by defining domains of cell differentiation. Nature 393:579-583

80. Aruga J, Mikoshiba K (2011) Role of BMP, FGF, calcium signaling, and Zic proteins in vertebrate neuroectodermal differentiation. Neurochem Res 36:1286-1292

81. Fernandes M, Gutin G, Alcorn H, McConnell SK, Hebert JM (2007) Mutations in the BMP pathway in mice support the existence of two molecular classes of holoprosencephaly. Development 134:3789-3794

82. Marchal L, Luxardi G, Thome V, Kodjabachian L (2009) BMP inhibition initiates neural induction via FGF signaling and Zic genes. Proc Natl Acad Sci USA 106:17437-17442

83. Moreau M, Neant I, Webb SE, Miller AL, Leclerc C (2008) Calcium signalling during neural induction in Xenopus laevis embryos. Philos Trans R Soc Lond B Biol Sci 363:13711375

84. Leclerc C, Webb SE, Daguzan C, Moreau M, Miller AL (2000) Imaging patterns of calcium transients during neural induction in Xenopus laevis embryos. J Cell Sci 113(Pt 19):3519-3529

85. Leclerc C, Lee M, Webb SE, Moreau M, Miller AL (2003) Calcium transients triggered by planar signals induce the expression of ZIC3 gene during neural induction in Xenopus. Dev Biol 261:381-390

86. Gutkovich YE, Ofir R, Elkouby YM, Dibner C, Gefen A, Elias S, Frank D (2010) Xenopus Meis3 protein lies at a nexus downstream to Zic1 and Pax3 proteins, regulating multiple cell-fates during early nervous system development. Dev Biol 338:50-62

87. Monsoro-Burq AH, Wang E, Harland R (2005) Msx 1 and Pax3 cooperate to mediate FGF8 and WNT signals during Xenopus neural crest induction. Dev Cell 8:167-178

88. Ishiguro A, Inoue T, Mikoshiba K, Aruga J (2004) Molecular properties of Zic4 and Zic5 proteins: functional diversity within Zic family. Biochem Biophys Res Commun 324:302-307

89. Coletta A, Pinney JW, Solis DY, Marsh J, Pettifer SR, Attwood TK (2010) Low-complexity regions within protein sequences have position-dependent roles. BMC Syst Biol 13:43

90. Pérez-Pérez JM, Candela H, Micol JL (2009) Understanding synergy in genetic interactions. Trends Genet 25:368-376

91. Zhu L, Zhou G, Poole S, Belmont JW (2008) Characterization of the interactions of human ZIC3 mutants with GLI3. Hum Mutat 29:99-105

92. Lim LS, Hong FH, Kunarso G, Stanton LW (2010) The pluripotency regulator Zic3 is a direct activator of the Nanog promoter in ESCs. Stem Cells 28:1961-1969 
93. Robasky K, Bulyk ML (2011) UniPROBE, update 2011: expanded content and search tools in the online database of protein-binding microarray data on protein-DNA interactions. Nucleic Acids Res 39:124-128

94. Fujimi TJ, Hatayama M, Aruga J (2012) Xenopus Zic3 controls notochord and organizer development through suppression of the Wnt/beta-catenin signaling pathway. Dev Biol 361:220-231

95. Zhu L, Harutyunyan KG, Peng JL, Wang J, Schwartz RJ, Belmont JW (2007) Identification of a novel role of ZIC3 in regulating cardiac development. Hum Mol Genet 16:1649-1660

96. Johnson DR (1976) The interfrontal bone and mutant genes in the mouse. J Anat 121:507-513
97. Aruga J, Mizugishi K, Koseki H, Imai K, Balling R, Noda T, Mikoshiba K (1999) Zic1 regulates the patterning of vertebral arches in cooperation with Gli3. Mech Dev 89:141-150

98. Aruga J, Tohmonda T, Homma S, Mikoshiba K (2002) Zic1 promotes the expansion of dorsal neural progenitors in spinal cord by inhibiting neuronal differentiation. Dev Biol 244:329-341

99. Richardson L, Venkataraman S, Stevenson P, Yang Y, Burton N, Rao J, Fisher M, Baldock RA, Davidson DR, Christiansen JH (2010) EMAGE mouse embryo spatial gene expression database: 2010 update. Nucl Acids Res 38:703-709 